\title{
LEVEL II SCOUR ANALYSIS FOR BRIDGE 16 (CHESVT01030016) on STATE ROUTE 103, crossing the WILLIAMS RIVER, CHESTER, VERMONT
}

U.S. Geological Survey Open-File Report 97-581

Prepared in cooperation with

VERMONT AGENCY OF TRANSPORTATION and

FEDERAL HIGHWAY ADMINISTRATION 


\section{LEVEL II SCOUR ANALYSIS FOR BRIDGE 16 (CHESVT01030016) on STATE ROUTE 103, crossing the WILLIAMS RIVER, CHESTER, VERMONT}

By MICHAEL A. IVANOFF AND ROBERT E. HAMMOND

U.S. Geological Survey Open-File Report 97-581

Prepared in cooperation with

VERMONT AGENCY OF TRANSPORTATION

and

FEDERAL HIGHWAY ADMINISTRATION 


\title{
U.S. DEPARTMENT OF THE INTERIOR BRUCE BABBITT, Secretary
}

\author{
U.S. GEOLOGICAL SURVEY \\ Gordon P. Eaton, Director
}

For additional information write to:

District Chief

U.S. Geological Survey 361 Commerce Way

Pembroke, NH 03275-3718
Copies of this report may be purchased from:

U.S. Geological Survey

Branch of Information Services

Open-File Reports Unit

Box 25286

Denver, CO 80225-0286 


\section{CONTENTS}

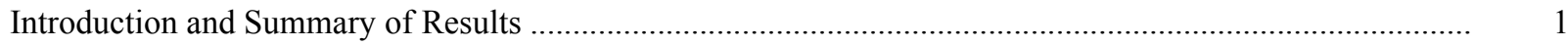

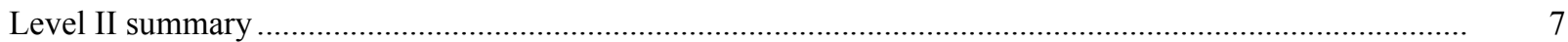

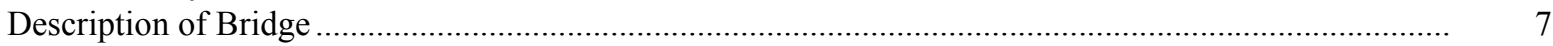

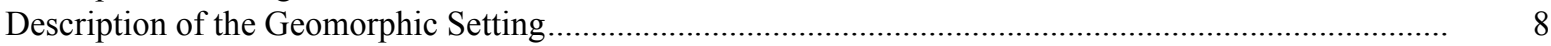

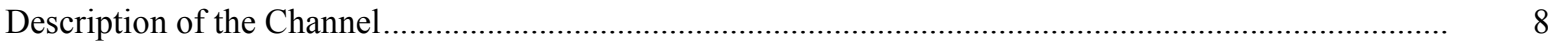

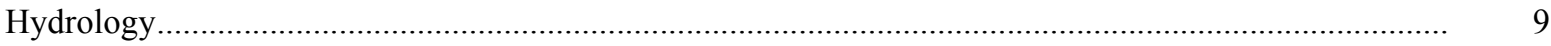

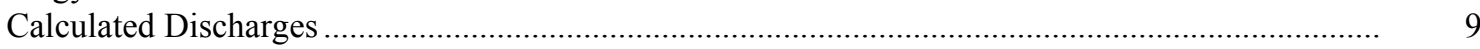

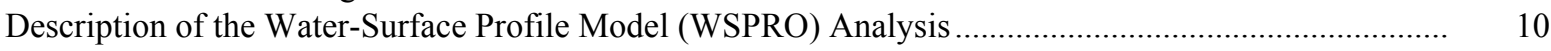

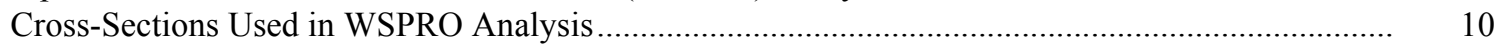

Data and Assumptions Used in WSPRO Model ...................................................................... 11

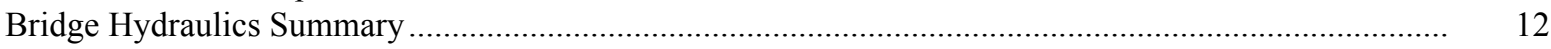

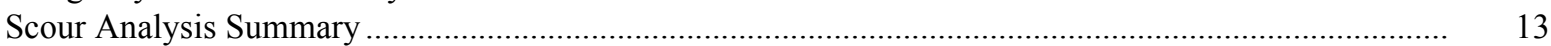

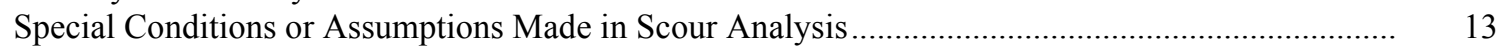

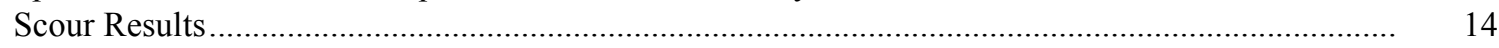

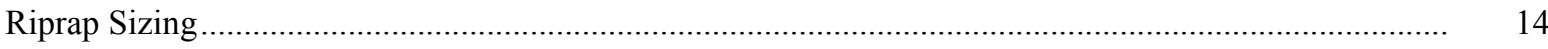



Appendixes:

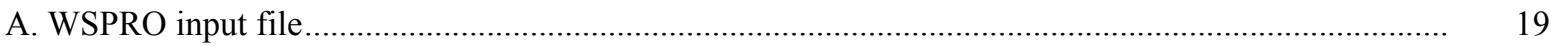

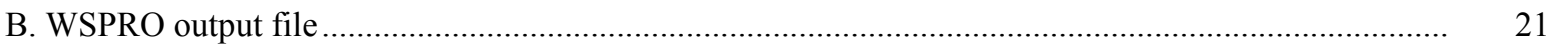



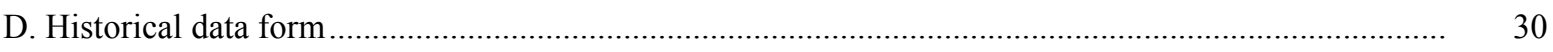

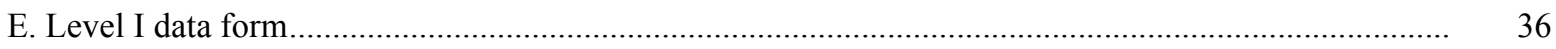

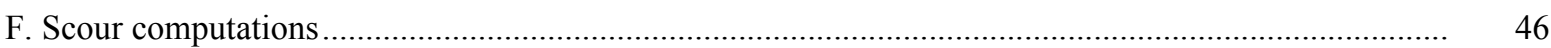

\section{FIGURES}

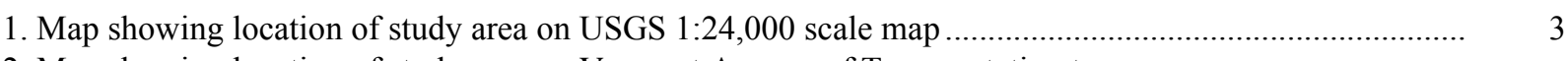

2. Map showing location of study area on Vermont Agency of Transportation town
highway map

3. Structure CHESVT01030016 viewed from upstream (September 16, 1996) ..........................................

4. Downstream channel viewed from structure CHESVT01030016 (September 16, 1996)........................ 5

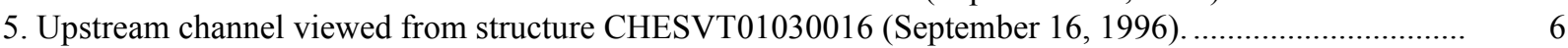

6. Structure CHESVT01030016 viewed from downstream (September 16, 1996)................................... 6

7. Water-surface profiles for the 100- and 500-year discharges at structure

CHESVT01030016 on State Route 103, crossing the Williams River,

Chester, Vermont..

8. Scour elevations for the 100- and 500-year discharges at structure

CHESVT01030016 on State Route 103, crossing the Williams River,

Chester, Vermont.

\section{TABLES}

1. Remaining footing/pile depth at abutments for the 100-year discharge at structure

CHESVT01030016 on State Route 103, crossing the Williams River,

Chester, Vermont

2. Remaining footing/pile depth at abutments for the 500-year discharge at structure

CHESVT01030016 on State Route 103, crossing the Williams River,

Chester, Vermont

6
(5 


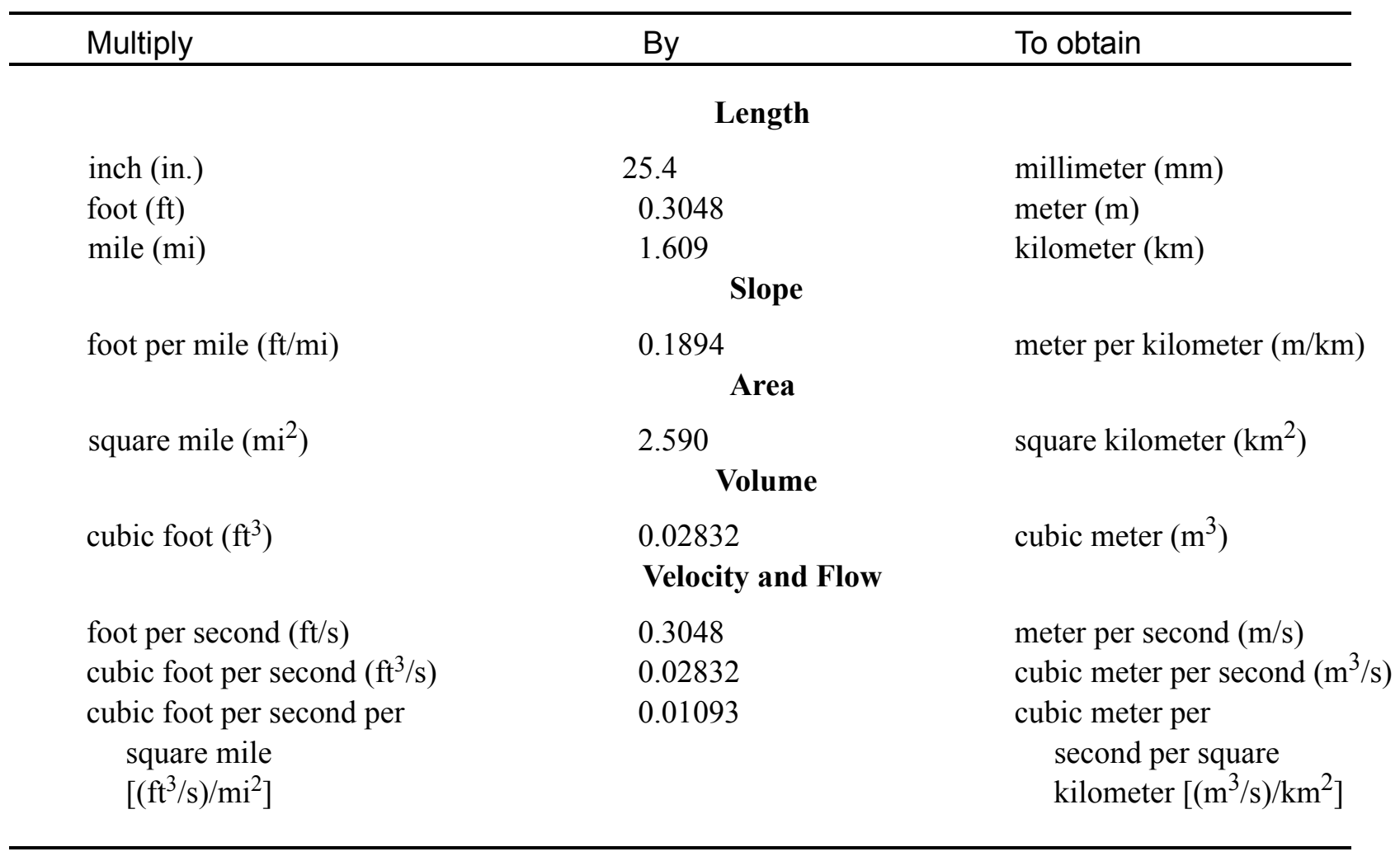

\section{OTHER ABBREVIATIONS}

$\begin{array}{lrlr}\mathrm{BF} & \text { bank full } & \text { LWW } & \text { left wingwall } \\ \mathrm{cfs} & \text { cubic feet per second } & \text { MC } & \text { main channel } \\ \mathrm{D}_{50} & \text { median diameter of bed material } & \text { RAB } & \text { right abutment } \\ \mathrm{DS} & \text { downstream } & \text { RABUT } & \text { face of right abutment } \\ \mathrm{elev} & \text { elevation } & \text { RB } & \text { right bank } \\ \mathrm{f} / \mathrm{p} & \text { flood plain } & \text { ROB } & \text { right overbank } \\ \mathrm{ft}^{2} & \text { square feet } & \text { RWW } & \text { right wingwall } \\ \mathrm{ft} / \mathrm{ft} & \text { feet per foot } & \text { TH } & \text { town highway } \\ \mathrm{JCT} & \text { junction } & \text { UB } & \text { under bridge } \\ \mathrm{LAB} & \text { left abutment } & \text { US } & \text { upstream } \\ \mathrm{LABUT} & \text { face of left abutment } & \text { USGS } & \text { United States Geological Survey } \\ \mathrm{LB} & \text { left bank } & \text { VTAOT Vermont Agency of Transportation } \\ \mathrm{LOB} & \text { left overbank } & \text { WSPRO } & \text { water-surface profile model }\end{array}$

In this report, the words "right" and "left" refer to directions that would be reported by an observer facing downstream. Sea level: In this report, "sea level" refers to the National Geodetic Vertical Datum of 1929-- a geodetic datum derived from a general adjustment of the first-order level nets of the United States and Canada, formerly called Sea Level Datum of 1929.

In the appendices, the above abbreviations may be combined. For example, USLB would represent upstream left bank. 


\title{
LEVEL II SCOUR ANALYSIS FOR BRIDGE 16 (CHESVT01030016) ON STATE ROUTE 103, CROSSING THE WILLIAMS RIVER, CHESTER, VERMONT
}

\author{
By Michael A. Ivanoff and Robert E. Hammond
}

\section{INTRODUCTION AND SUMMARY OF RESULTS}

This report provides the results of a detailed Level II analysis of scour potential at structure CHESVT01030016 on State Route 103 crossing the Williams River, Chester, Vermont (figures 1-8). A Level II study is a basic engineering analysis of the site, including a quantitative analysis of stream stability and scour (U.S. Department of Transportation, 1993). Results of a Level I scour investigation also are included in Appendix E of this report. A Level I investigation provides a qualitative geomorphic characterization of the study site. Information on the bridge, gleaned from Vermont Agency of Transportation (VTAOT) files, was compiled prior to conducting Level I and Level II analyses and is found in Appendix D.

The site is in the New England Upland section of the New England physiographic province in southeastern Vermont. The $15.1-\mathrm{mi}^{2}$ drainage area is in a predominantly rural and forested basin. In the vicinity of the study site, the surface cover is pasture except for the downstream right overbank which is forested.

In the study area, the Williams River has an incised, straight channel with a slope of approximately $0.008 \mathrm{ft} / \mathrm{ft}$, an average channel top width of $56 \mathrm{ft}$ and an average bank height of $6 \mathrm{ft}$. The channel bed material ranges from gravel to cobbles with a median grain size $\left(\mathrm{D}_{50}\right)$ of $67.5 \mathrm{~mm}(0.222 \mathrm{ft})$. The geomorphic assessment at the time of the Level I and Level II site visit on September 16, 1996, indicated that the reach was stable.

The State Route 103 crossing of the Williams River is a 162-ft-long, two-lane bridge consisting of three steel-beam spans (Vermont Agency of Transportation, written communication, March 13, 1995). The opening length of the structure parallel to the bridge face is $157.7 \mathrm{ft}$.The bridge is supported by vertical, concrete abutments and piers with no wingwalls. The channel is skewed approximately 55 degrees to the opening while the opening-skew-to-roadway is also 55 degrees. 
The scour protection measures at the site included type-4 stone fill (less than 60 inches diameter) along the upstream left bank. There was type-3 stone fill (less than 48 inches diameter) along the upstream right bank and both spill-through embankments and both downstream banks. There was type-1 stone fill (less than 12 inches diameter) along the upstream right and downstream left road embankments. Additional details describing conditions at the site are included in the Level II Summary and Appendices D and E.

Scour depths and recommended rock rip-rap sizes were computed using the general guidelines described in Hydraulic Engineering Circular 18 (Richardson and others, 1995). Total scour at a highway crossing is comprised of three components: 1) long-term streambed degradation; 2) contraction scour (due to accelerated flow caused by a reduction in flow area at a bridge) and; 3 ) local scour (caused by accelerated flow around piers and abutments). Total scour is the sum of the three components. Equations are available to compute depths for contraction and local scour and a summary of the results of these computations follows.

Contraction scour for all modelled flows was 0.0. Abutment scour ranged from 6.4 to $9.0 \mathrm{ft}$. The worst-case abutment scour occurred at the 500-year discharge. Pier scour ranged from 7.9 to $10.1 \mathrm{ft}$. The worst-case pier scour occurred at the incipient-overtopping discharge for both piers. Additional information on scour depths and depths to armoring are included in the section titled "Scour Results". Scoured-streambed elevations, based on the calculated scour depths, are presented in tables 1 and 2. A cross-section of the scour computed at the bridge is presented in figure 8 . Scour depths were calculated assuming an infinite depth of erosive material and a homogeneous particle-size distribution.

It is generally accepted that the Froehlich equation (abutment scour) gives "excessively conservative estimates of scour depths" (Richardson and others, 1995, p. 47). Usually, computed scour depths are evaluated in combination with other information including (but not limited to) historical performance during flood events, the geomorphic stability assessment, existing scour protection measures, and the results of the hydraulic analyses. Therefore, scour depths adopted by VTAOT may differ from the computed values documented herein. 


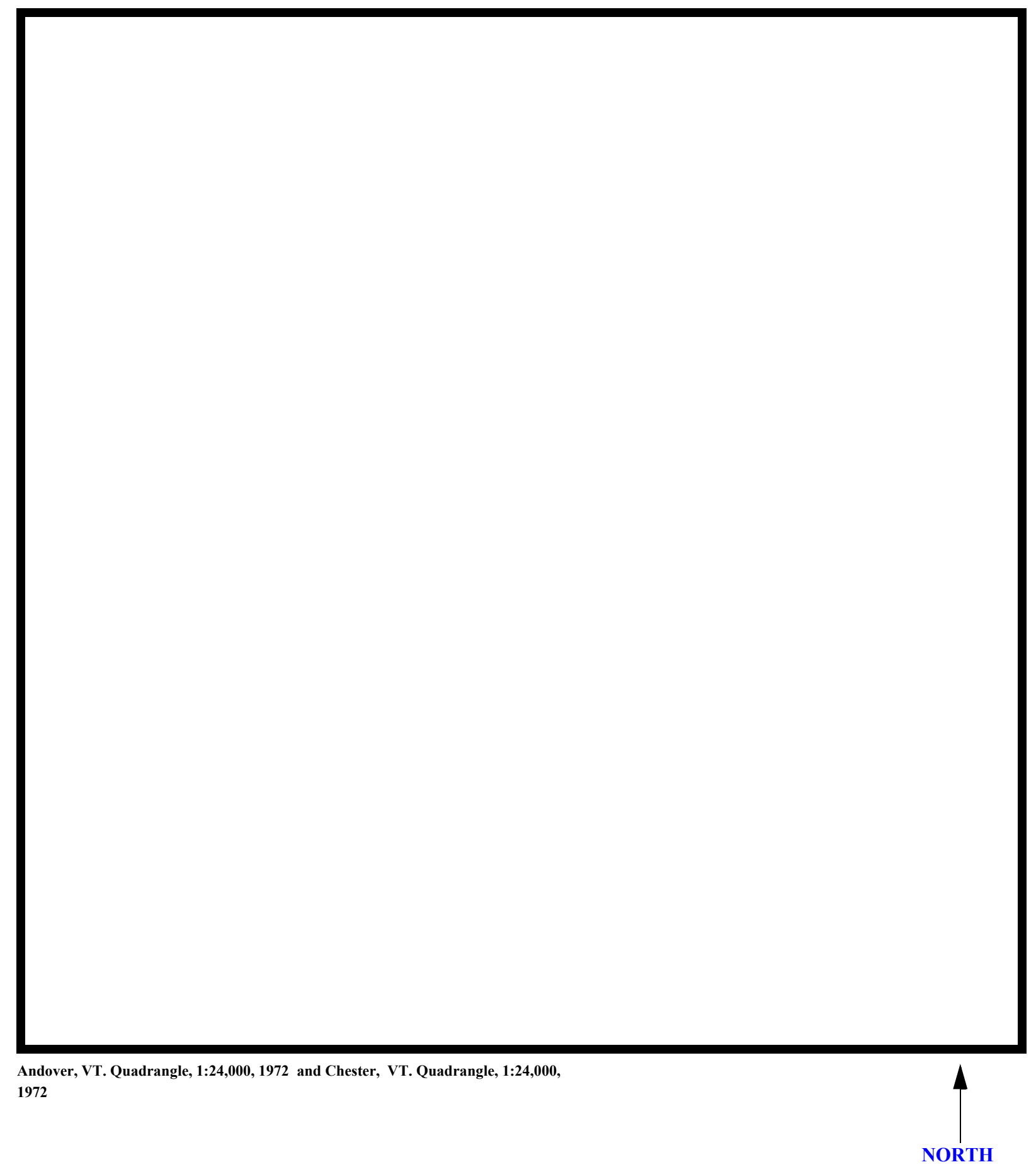

Figure 1. Location of study area on USGS 1:24,000 scale map. 
Figure 2. Location of study area on Vermont Agency of Transportation town highway map. 

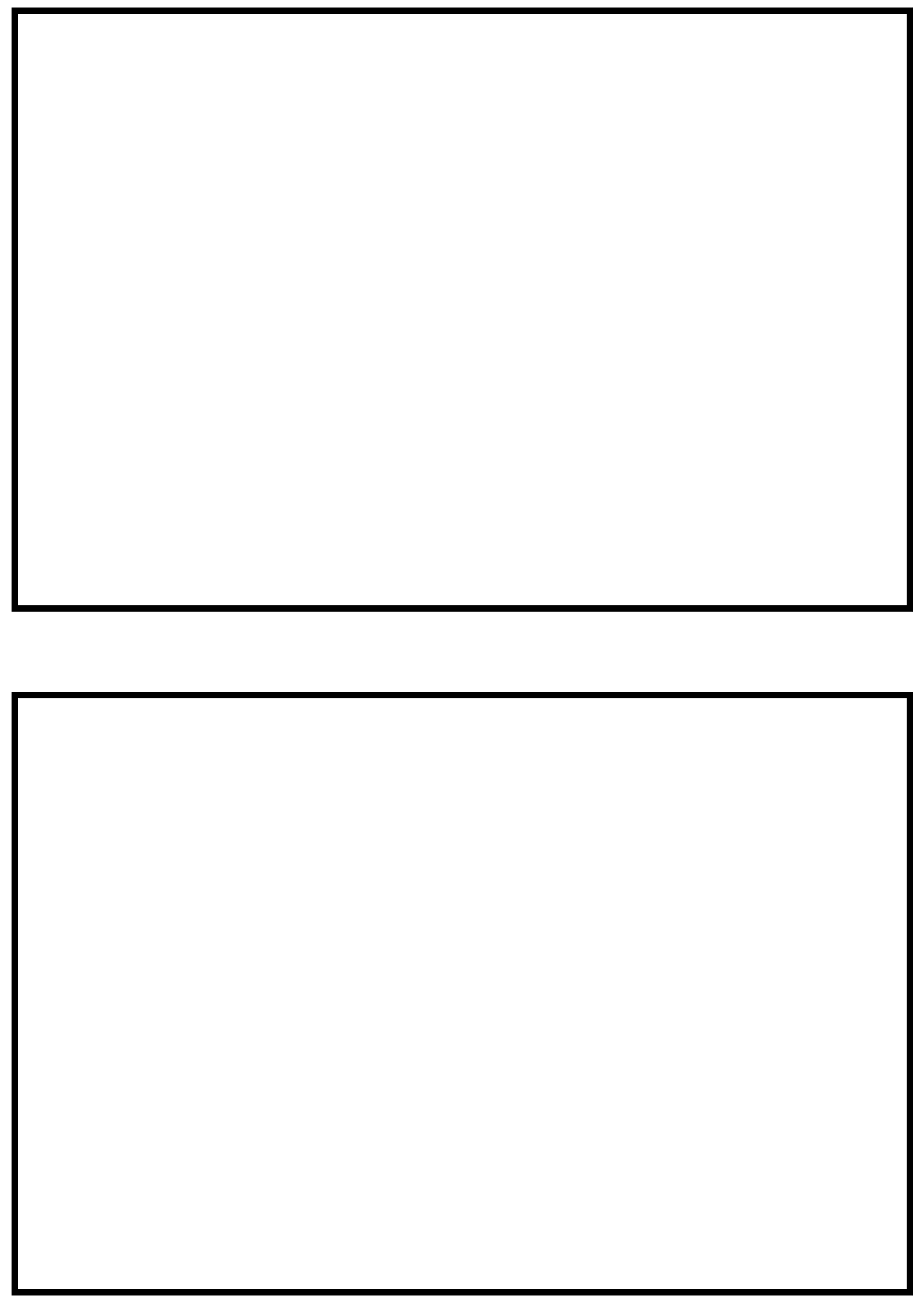




\section{LEVEL II SUMMARY}

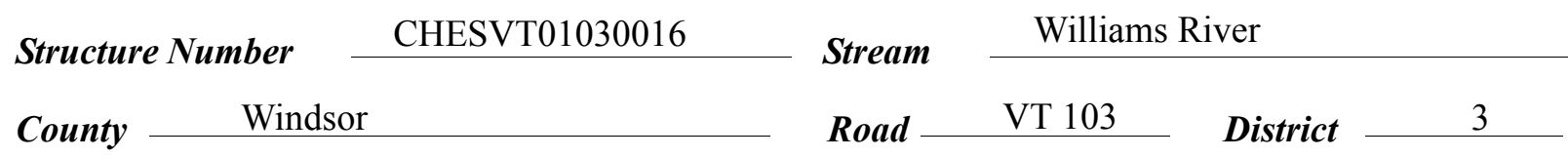

\section{Description of Bridge}

Bridge length $\frac{162}{f t}$ Bridge width $\quad 35.2 \quad$ Max span length $\stackrel{87}{f t}$ Alignment of bridge to road (on curve or straight) Spill-through Abutment type

Stone fill on abutment?

$$
\text { Yes }
$$

\section{namaintin.. sf ats... fill} Type-4, along the upstream left bank. Type-3, along the upstream right bank, both spill-through embankments, and the downstream banks. Type-1, at the upstream right and downstream left road embankments.

Abutments and piers are concrete. There is stone fill between the abutments and piers forming a spill-through embankment to the stream channel. Yes

Is bridge skewed to flood flow according to survey?
9/16/96

Debris accumulation on bridge at time of Level I or Level II site visit:

$$
\begin{gathered}
\text { Date af insnortion } \\
0
\end{gathered} \quad \begin{gathered}
\text { Percent of ahmmal } \\
\text { blocked inortzontatl }
\end{gathered}
$$$$
96
$$

Level I

Level II$$
0
$$

Percent o: $9 / 16 /$
blocked verticatty 0 over the channel upstream.

Potential for debris

None as of 9/16/96.

Doscriho any, foaturos noar ar at tho hridos that mav, affoct flou, (includo ahsorvation dato) 


\section{Description of the Geomorphic Setting}

General topography The channel is located within a moderate relief valley.

Geomorphic conditions at bridge site: downstream (DS), upstream (US)

Date of inspection $\quad 9 / 16 / 96$

DS left: $\quad$ Moderately sloped overbank.

DS right: $\quad$ Steep channel bank to a moderately sloped overbank.

US left: $\quad$ Steep channel bank and valley wall.

US right: $\quad$ Moderately sloped channel bank to a narrow flood plain.

\section{Description of the Channel}

$\begin{array}{llll}\text { Average top width } & 56 & \text { Average depth } & 6 \\ & \text { Gravel / Cobbles } & \text { Gravel/Cobbles }\end{array}$

Predominant bed material

Bank material Straight and stable

with semi-allúvial channel boundaries.

9/16/96

Vegetative co 1 Trees and brush.

DS left: $\quad$ Trees and brush.

DS right: $\quad$ Trees and brush.

US left: $\quad$ Trees and brush.

US right: $\quad$ Yes

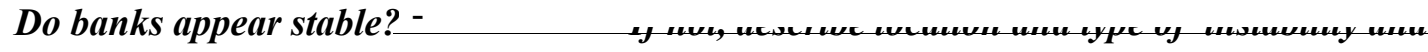

date of observation.

None noted 9/16/96.

Describe any obstructions in channel and date of observation. 


\title{
Hydrology
}

Drainage area $\stackrel{15.1}{\mathrm{mi}^{2}}$

Percentage of drainage area in physiographic provinces: (approximate)

Physiographic province/section New England/New England Upland
Percent of drainage area 100

\begin{abstract}
Is drainage area considered rural or urban?
Rural urbanization:

Describe any significant
\end{abstract}

Yes

Is there a USGS gage on the stream of interest? Williams River at Brockways Mills, VT USGS gage description 01153500

USGS gage number 103

Gage drainage area $\mathrm{mi}^{2}$ No

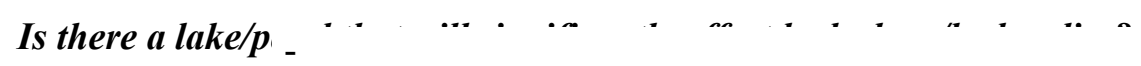

\begin{tabular}{|c|c|c|c|}
\hline 3,910 & & rges & 5,740 \\
\hline 100 & $f t^{3} / s$ & $Q 500$ & \\
\hline
\end{tabular}

The 100- and 500-year discharges are based on

flood frequency estimates available in the Flood Insurance Study for Chester, VT (Federal Emergency Management Agency, 1982). These values are within a range defined by several empirical flood frequency curves (Benson, 1962; Johnson and Tasker, 1974; FHWA, 1983;

Potter, 1957a\&b; Talbot, 1887). 


\section{Description of the Water-Surface Profile Model (WSPRO) Analysis}

Datum for WSPRO analysis (USGS survey, sea level, VTAOT plans)

USGS survey

Datum tie between USGS survey and VTAOT plans

Add $330.8 \mathrm{ft}$. to the USGS

arbitrary survey datum to obtain VTAOT plans' datum.

Description of reference marks used to determine USGS datum. $\quad$ RM1 is a State of

Vermont brass tablet on top of the right end of the downstream curb (elev. $497.33 \mathrm{ft}$, arbitrary

survey datum). RM2 is a chiseled X on top of the left end of the downstream curb (elev. 499.76

$\mathrm{ft}$, arbitrary survey datum).

\section{Cross-Sections Used in WSPRO Analysis}

\begin{tabular}{|c|c|c|c|}
\hline${ }^{1}$ Cross-section & $\begin{array}{c}\text { Section } \\
\text { Reference } \\
\text { Distance } \\
\text { (SRD) in feet }\end{array}$ & $\begin{array}{c}{ }^{2} \text { Cross-section } \\
\text { development }\end{array}$ & Comments \\
\hline EXITX & -153 & 1 & Exit section \\
\hline FULLV & 0 & 2 & $\begin{array}{l}\text { Downstream Full-valley } \\
\text { section (Templated from } \\
\text { EXITX) }\end{array}$ \\
\hline BRIDG & 0 & 1 & Bridge section \\
\hline RDWAY & 29 & 1 & Road Grade section \\
\hline APPRO & 149 & 2 & $\begin{array}{l}\text { Modelled Approach sec- } \\
\text { tion (Templated from } \\
\text { APTEM) }\end{array}$ \\
\hline APTEM & 221 & 1 & $\begin{array}{l}\text { Approach section as sur- } \\
\text { veyed (Used as a tem- } \\
\text { plate) }\end{array}$ \\
\hline
\end{tabular}

${ }^{1}$ For location of cross-sections see plan-view sketch included with Level I field form, Appendix E. For more detail on how cross-sections were developed see WSPRO input file. 


\section{Data and Assumptions Used in WSPRO Model}

Hydraulic analyses of the reach were done by use of the Federal Highway Administration's WSPRO step-backwater computer program (Shearman and others, 1986, and Shearman, 1990). The analyses reported herein reflect conditions existing at the site at the time of the study. Furthermore, in the development of the model it was necessary to assume no accumulation of debris or ice at the site. Results of the hydraulic model are presented in the Bridge Hydraulic Summary, Appendix B, and figure 7.

Channel roughness factors (Manning's " $n$ ") used in the hydraulic model were estimated using field inspections at each cross section following the general guidelines described by Arcement and Schneider (1989). Final adjustments to the values were made during the modelling of the reach. Channel " $n$ " values for the reach ranged from 0.045 to 0.050 , and overbank " $\mathrm{n}$ " values ranged from 0.035 to 0.070 .

Normal depth at the exit section (EXITX) was assumed as the starting water surface. This depth was computed by use of the slope-conveyance method outlined in the user's manual for WSPRO (Shearman, 1990). The slope used was $0.008 \mathrm{ft} / \mathrm{ft}$, which was the slope of the 100year water surface profile from the Flood Insurance Study for the Town of Chester (Federal Emergency Management Agency, 1982).

The surveyed approach section (APTEM) was moved along the approach channel slope $(0.0083 \mathrm{ft} / \mathrm{ft})$ to establish the modelled approach section (APPRO), one bridge length upstream of the upstream face as recommended by Shearman and others (1986). This location also provides a consistent method for determining scour variables. 


\section{Bridge Hydraulics Summary}

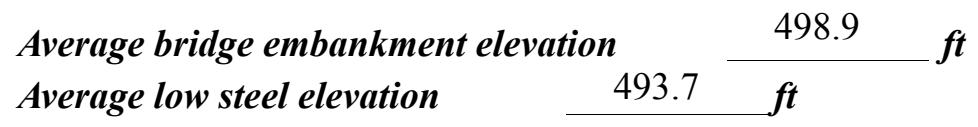

100-year discharge $\quad 3,910 \quad \mathrm{ft}^{3} / \mathrm{s}$

Water-surface elevation in bridge opening $\quad 491.9 \quad f t$

Road overtopping? ___ No Discharge over road ___ -- $\mathrm{ft}^{3} / \mathrm{s}$

Area of flow in bridge opening $\quad 452 \quad \mathrm{ft}^{2}$

Average velocity in bridge opening $\quad 8.6 \quad \mathrm{ft} / \mathrm{s}$

Maximum WSPRO tube velocity at bridge $10.5 \mathrm{ft} / \mathrm{s}$

Water-surface elevation at Approach section with bridge 493.0

$\begin{array}{ll}\text { Water-surface elevation at Approach section without bridge } & 493.1\end{array}$

Amount of backwater caused by bridge N/A it

500-year discharge $\quad 5,740 \quad \mathrm{ft}^{3} / \mathrm{s}$

Water-surface elevation in bridge opening $\quad 493.7$ ft

Road overtopping? ____ Yes Discharge over road __ 1,327 $\mathrm{ft}^{3} / \mathrm{s}$

\begin{tabular}{llll} 
Area of flow in bridge opening & 522 & $\boldsymbol{f t}^{2}$ & \\
\cline { 2 - 4 } Average velocity in bridge opening & & 8.4 & $\mathbf{f t} / \mathbf{s}$
\end{tabular}

Maximum WSPRO tube velocity at bridge 10.3 , s

Water-surface elevation at Approach section with bridge 496.0

Water-surface elevation at Approach section without bridge $\quad 494.9$

Amount of backwater caused by bridge $\quad 1.1, t$

Incipient overtopping discharge $\quad 5,420 \quad \mathrm{ft}^{3} / \mathrm{s}$

Water-surface elevation in bridge opening $492.7 \quad$ t

Area of flow in bridge opening $\quad 506 \quad \mathrm{ft}^{2}$

Average velocity in bridge opening $\quad 10.7 \quad \mathrm{ft} / \mathrm{s}$

Maximum WSPRO tube velocity at bridge $13.3 \mathrm{ft} / \mathrm{s}$

Water-surface elevation at Approach section with bridge

Water-surface elevation at Approach section without bridge

494.1

Amount of backwater caused by bridge $\quad 0.1$, t

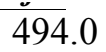




\section{Scour Analysis Summary}

\section{Special Conditions or Assumptions Made in Scour Analysis}

Scour depths were computed using the general guidelines described in Hydraulic Engineering Circular 18 (Richardson and others, 1995). Scour depths were calculated assuming an infinite depth of erosive material and a homogeneous particle-size distribution. The results of the scour analysis are presented in tables 1 and 2 and a graph of the scour depths is presented in figure 8 .

Contraction scour for the 100-year and incipient-overtopping discharges were computed by use of the live-bed contraction scour equation (Richardson and others, 1995, p. 30, equation 17). At this site, the 500-year discharge resulted in unsubmerged orifice flow. Contraction scour at bridges with orifice flow is best estimated by use of the Chang pressure-flow scour equation (oral communication, J. Sterling Jones, October 4, 1996). Thus, contraction scour for the 500-year discharge was computed by use of the Chang equation (Richardson and others, 1995,p. 145-146). Results of this analysis are presented in figure 8 and tables 1 and 2 . The streambed armoring depths computed suggest that armoring will not limit the depth of contraction scour.

For the discharge resulting in orifice flow, estimates of contraction scour were also computed by use of the Laursen clear-water contraction scour equation and the Umbrell pressureflow equation (Richardson and others, 1995, p. 144) and presented in Appendix F. Furthermore, since this discharge resulted in unsubmerged orifice flow, contraction scour was computed by substituting an estimate for the depth of flow at the downstream bridge face in the contraction scour equations. Results with respect to this substitution is provided in Appendix F.

Abutment scour was computed by use of the Froehlich equation (Richardson and others, 1995, p. 48, equation 28). Variables for the Froehlich equation include the Froude number of the flow approaching the embankments, the length of the embankment blocking flow, and the depth of flow approaching the embankment less any roadway overtopping. At the 100-year discharge, there is no computed abutment scour because the bridge abutments do not constrict the flow.

Because the influence of scour processes on the spill-through embankment material is uncertain, the scour depth at the vertical concrete abutment walls is unknown. Therefore, the scour depths were applied for the entire spill-through embankment below the elevation at the toe of each embankment in figure 8.

Pier scour was computed by use of the Colorado State University pier scour equation (Richardson and others, 1995, p. 36, equation 21). Variables for the Colorado State University pier scour equation include the Froude number of the flow approaching the pier, pier width ratio to the depth of flow, pier length, and correction factors for the pier nose shape, angle of attack of flow, bed condition, and armoring by bed material size. The angle of repose depicted in figure 8 is arbitrary. 


\section{Scour Results}

100-yr discharge 500-yr discharge

Incipient

overtopping

Contraction scour:

(Scour depths in feet)

Main channel

Live-bed scour

Clear-water scour

Depth to armoring

Left overbank

Right overbank

Local scour:

Abutment scour

Left abutment

0.0

7.2

7.0

$0.0_{-}$

9.0

6.4 .

Right abutment

Pier scour

Pier 1

7.9

8.6

10.1

7.9

8.6

10.1

Pier 2

Pier 3

Abutments:

Left abutment

Right abutment

Piers:

Pier 1

Pier 2

\section{Riprap Sizing}

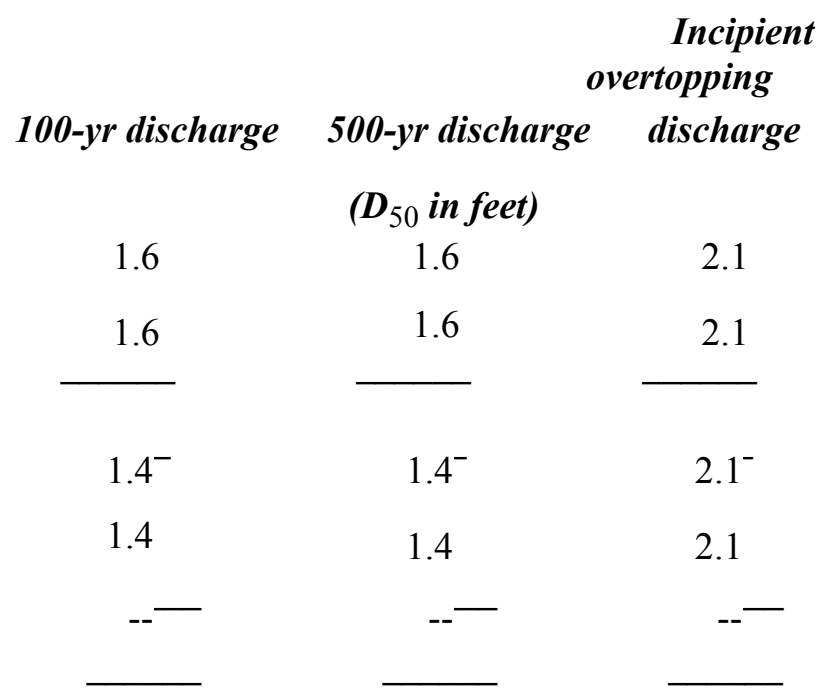




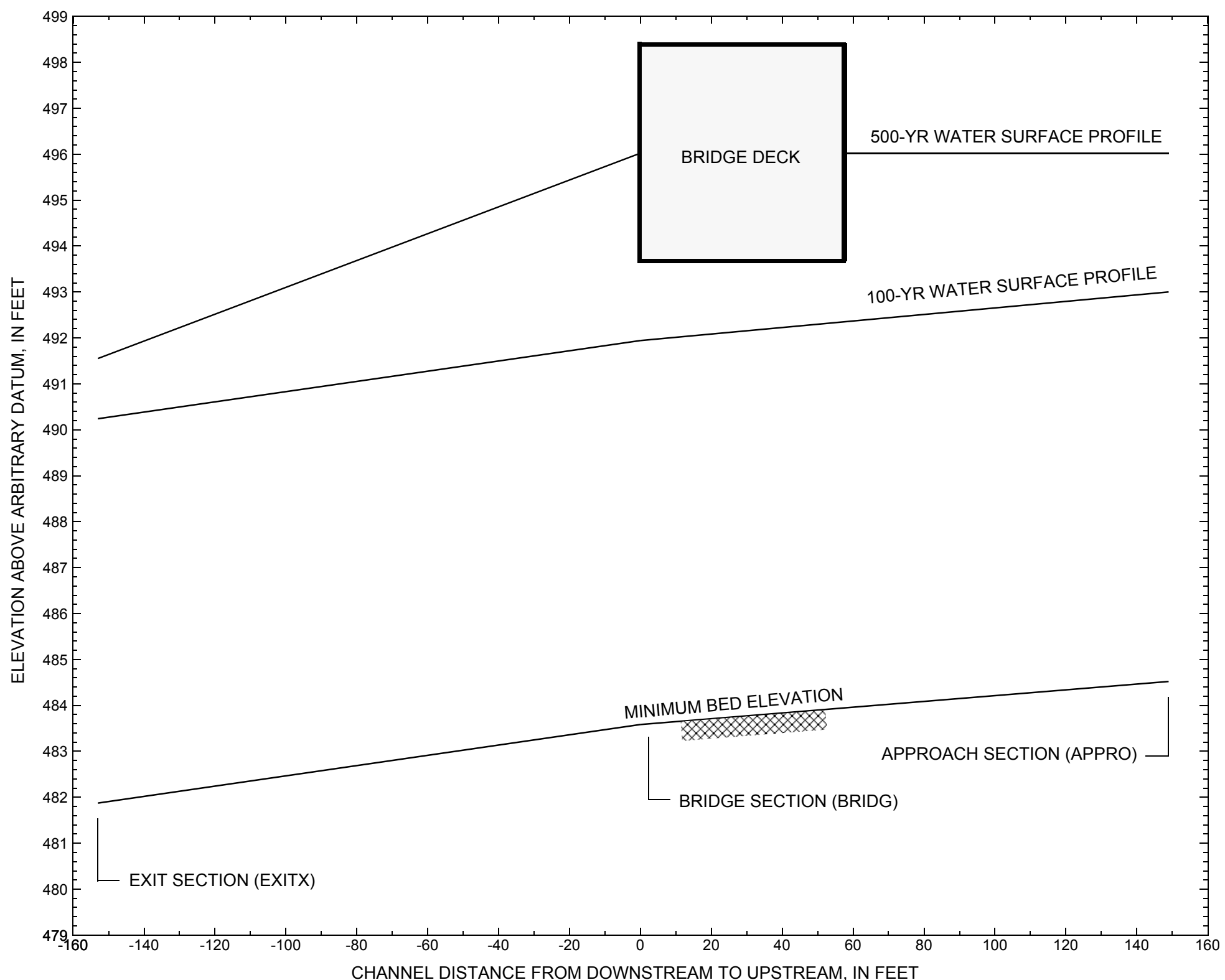

Figure 7. Water-surface profiles for the 100- and 500-yr discharges at structure CHESVT01030016 on State Route 103, crossing the Williams River, Chester, Vermont. 


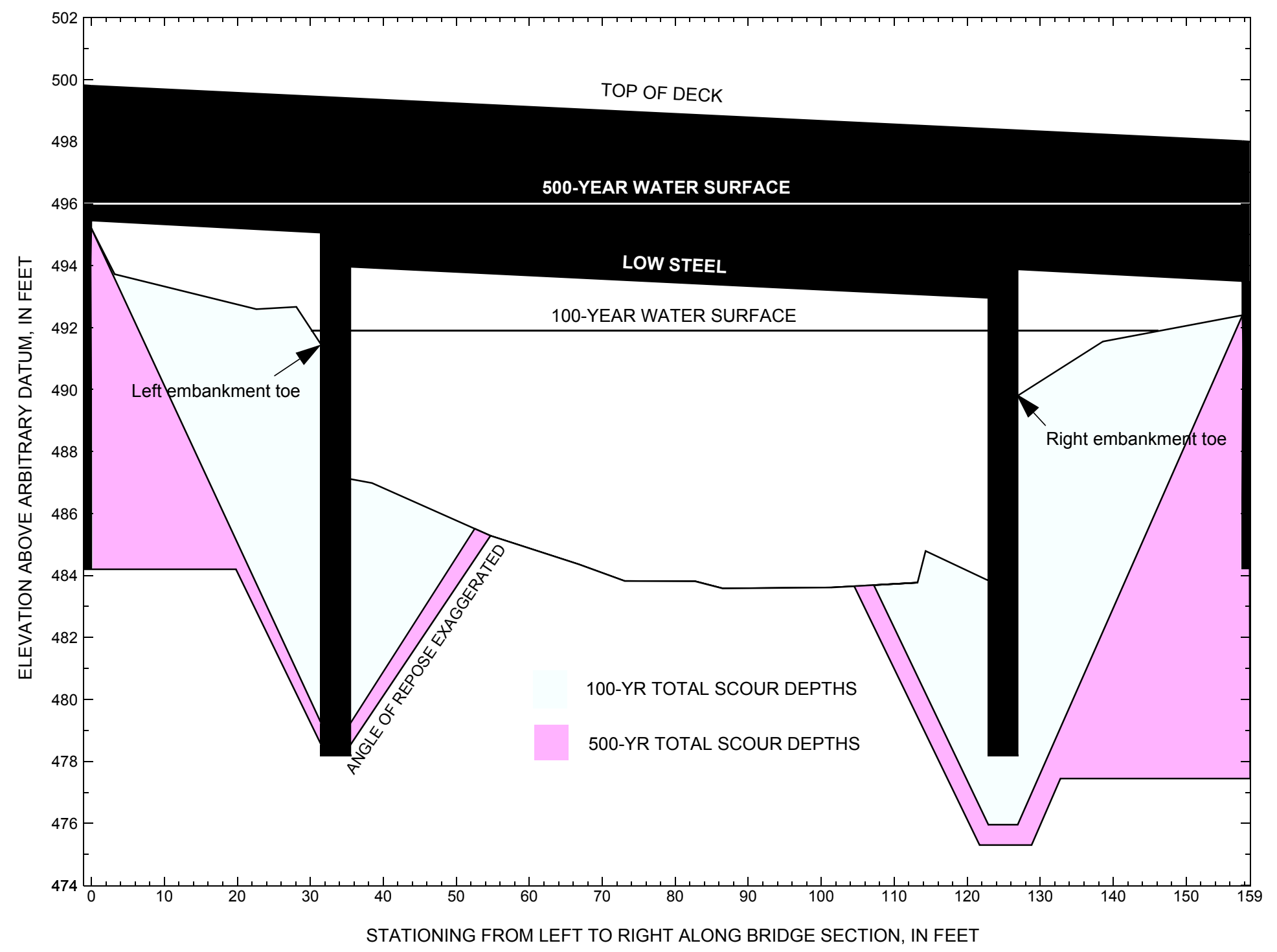

Figure 8. Scour elevations for the 100-yr and 500-yr discharges at structure CHESVT01030016 on State Route 103, crossing the Williams River, Chester, Vermont. 


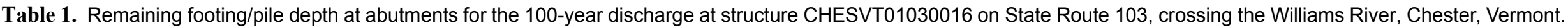
[VTAOT, Vermont Agency of Transportation; --,no data]

\begin{tabular}{|c|c|c|c|c|c|c|c|c|c|c|c|}
\hline Description & Station $^{1}$ & $\begin{array}{l}\text { VTAOT } \\
\text { minimum } \\
\text { bridge seat } \\
\text { elevation } \\
\text { (feet) }\end{array}$ & $\begin{array}{l}\text { Surveyed } \\
\text { minimum } \\
\text { low-chord } \\
\text { elevation }{ }^{2} \\
\text { (feet) }\end{array}$ & $\begin{array}{l}\text { Bottom of } \\
\text { footing } \\
\text { elevation } \\
\text { (feet) }\end{array}$ & $\begin{array}{c}\text { Channel } \\
\text { elevation at } \\
\text { abutment/ } \\
\text { pier }^{2} \\
\text { (feet) }\end{array}$ & $\begin{array}{l}\text { Contraction } \\
\text { scour depth } \\
\text { (feet) }\end{array}$ & $\begin{array}{l}\text { Abutment } \\
\text { scour } \\
\text { depth } \\
\text { (feet) }\end{array}$ & $\begin{array}{l}\text { Pier } \\
\text { scour } \\
\text { depth } \\
\text { (feet) }\end{array}$ & $\begin{array}{l}\text { Depth of } \\
\text { total scour } \\
\text { (feet) }\end{array}$ & $\begin{array}{c}\text { Elevation of } \\
\text { scour }^{2} \\
\text { (feet) }\end{array}$ & $\begin{array}{c}\text { Remaining } \\
\text { footing/pile } \\
\text { depth } \\
\text { (feet) }\end{array}$ \\
\hline \multicolumn{12}{|c|}{100 -yr. discharge is 3,910 cubic-feet per second } \\
\hline Left abutment & 0.0 & 495.2 & 495.4 & 484.2 & 492.3 & 0.0 & -- & -- & 0.0 & -- & 0.0 \\
\hline Left embankment toe & 31.5 & -- & -- & -- & 491.4 & 0.0 & 0.0 & -- & 0.0 & 491.4 & -- \\
\hline Pier 1 & 33.5 & -- & -- & 478.2 & 487.1 & 0.0 & -- & 7.9 & 7.9 & 479.2 & 1.0 \\
\hline Pier 2 & 124.9 & -- & -- & 478.2 & 483.9 & 0.0 & -- & 7.9 & 7.9 & 476.0 & -2.2 \\
\hline Right embankment toe & 126.9 & -- & -- & -- & 486.4 & 0.0 & 0.0 & -- & 0.0 & 486.4 & -- \\
\hline Right abutment & 157.7 & 493.3 & 493.5 & 484.2 & 491.0 & 0.0 & -- & -- & 0.0 & -- & 0.0 \\
\hline
\end{tabular}

1.Measured along the face of the most constricting side of the bridge.

2.Arbitrary datum for this study.

Table 2. Remaining footing/pile depth at abutments for the 500-year discharge at structure CHESVT01030016 on State Route 103, crossing the Williams River, Chester, Vermont.

[VTAOT, Vermont Agency of Transportation; --, no data]

\begin{tabular}{|c|c|c|c|c|c|c|c|c|c|c|c|}
\hline Description & Station $^{1}$ & $\begin{array}{c}\text { VTAOT } \\
\text { minimum } \\
\text { bridge seat } \\
\text { elevation } \\
\text { (feet) }\end{array}$ & $\begin{array}{l}\text { Surveyed } \\
\text { minimum } \\
\text { low-chord } \\
\text { elevation } \\
\quad \text { (feet) }\end{array}$ & $\begin{array}{c}\text { Bottom of } \\
\text { footing } \\
\text { elevation }{ }^{2} \\
\text { (feet) }\end{array}$ & $\begin{array}{c}\text { Channel } \\
\text { elevation at } \\
\text { abutment/ } \\
\text { pier }^{2} \\
\text { (feet) }\end{array}$ & $\begin{array}{l}\text { Contraction } \\
\text { scour depth } \\
\text { (feet) }\end{array}$ & $\begin{array}{l}\text { Abutment } \\
\text { scour } \\
\text { depth } \\
\text { (feet) }\end{array}$ & $\begin{array}{l}\text { Pier } \\
\text { scour } \\
\text { depth } \\
\text { (feet) }\end{array}$ & $\begin{array}{l}\text { Depth of } \\
\text { total scour } \\
\text { (feet) }\end{array}$ & $\begin{array}{c}\text { Elevation of } \\
\text { scour }^{2} \\
\text { (feet) }\end{array}$ & $\begin{array}{c}\text { Remaining } \\
\text { footing/pile } \\
\text { depth } \\
\text { (feet) }\end{array}$ \\
\hline \multicolumn{12}{|c|}{500 -yr. discharge is 5,740 cubic-feet per second } \\
\hline Left abutment & 0.0 & 495.2 & 495.4 & 484.2 & 492.3 & 0.0 & -- & -- & 0.0 & -- & 0.0 \\
\hline Left embankment toe & 31.5 & -- & -- & -- & 491.4 & 0.0 & 7.2 & -- & 7.2 & 484.2 & -- \\
\hline Pier 1 & 33.5 & -- & -- & 478.2 & 487.1 & 0.0 & -- & 8.6 & 8.6 & 478.5 & 0.3 \\
\hline Pier 2 & 124.9 & -- & -- & 478.2 & 483.9 & 0.0 & -- & 8.6 & 8.6 & 475.3 & -2.9 \\
\hline Right embankment toe & 126.9 & -- & -- & -- & 486.4 & 0.0 & 9.0 & -- & 9.0 & 477.4 & -- \\
\hline Right abutment & 157.7 & 493.3 & 493.5 & 484.2 & 491.0 & 0.0 & -- & -- & 0.0 & -- & $-6.8 v p$ \\
\hline
\end{tabular}

1.Measured along the face of the most constricting side of the bridge.

2.Arbitrary datum for this study. 


\section{SELECTED REFERENCES}

Arcement, G.J., Jr., and Schneider, V.R., 1989, Guide for selecting Manning's roughness coefficients for natural channels and flood plains: U.S. Geological Survey Water-Supply Paper 2339, 38 p.

Barnes, H.H., Jr., 1967, Roughness characteristics of natural channels: U.S. Geological Survey Water-Supply Paper 1849,213 p.

Benson, M. A., 1962, Factors Influencing the Occurrence of Floods in a Humid Region of Diverse Terrain: U.S. Geological Survey WaterSupply Paper 1580-B, 64 p.

Brown, S.A. and Clyde, E.S., 1989, Design of riprap revetment: Federal Highway Administration Hydraulic Engineering Circular No. 11, Publication FHWA-IP-89-016, 156 p.

Federal Highway Administration, 1983, Runoff estimates for small watersheds and development of sound design: Federal Highway Administration Report FHWA-RD-77-158.

Federal Highway Administration, 1993, Stream Stability and Scour at Highway Bridges: Participant Workbook: Federal Highway Administration Report FHWA-HI-91-011.

Federal Emergency Management Agency, 1982, Flood Insurance Study, Town of Chester, Windsor County, Vermont: Washington, D.C., February 1982.

Froehlich, D.C., 1989, Local scour at bridge abutments in Ports, M.A., ed., Hydraulic Engineering--Proceedings of the 1989 National Conference on Hydraulic Engineering: New York, American Society of Civil Engineers, p. 13-18.

Hayes, D.C.,1993, Site selection and collection of bridge-scour data in Delaware, Maryland, and Virginia: U.S. Geological Survey WaterResources Investigation Report 93-4017, 23 p.

Interagency Advisory Committee on Water Data, 1982, Guidelines for determining flood flow frequency: U.S. Geological Survey, Bulletin 17B of the Hydrology Subcommittee, $190 \mathrm{p}$.

Johnson, C.G. and Tasker, G.D.,1974, Progress report on flood magnitude and frequency of Vermont streams: U.S. Geological Survey OpenFile Report 74-130, 37 p.

Lagasse, P.F., Schall, J.D., Johnson, F., Richardson, E.V., Chang, F., 1995, Stream Stability at Highway Structures: Federal Highway Administration Hydraulic Engineering Circular No. 20, Publication FHWA-IP-90-014, 144 p.

Laursen, E.M., 1960, Scour at bridge crossings: Journal of the Hydraulics Division, American Society of Civil Engineers, v. 86, no. HY2, p. 39-53.

Potter, W. D., 1957a, Peak rates of runoff in the Adirondack, White Mountains, and Maine woods area, Bureau of Public Roads

Potter, W. D., 1957b, Peak rates of runoff in the New England Hill and Lowland area, Bureau of Public Roads

Richardson, E.V. and Davis, S.R., 1995, Evaluating scour at bridges: Federal Highway Administration Hydraulic Engineering Circular No. 18, Publication FHWA-IP-90-017, 204 p.

Richardson, E.V., Simons, D.B., and Julien, P.Y., 1990, Highways in the river environment: Federal Highway Administration Publication FHWA-HI-90-016.

Ritter, D.F., 1984, Process Geomorphology: W.C. Brown Co., Debuque, Iowa, 603 p.

Shearman, J.O., 1990, User's manual for WSPRO--a computer model for water surface profile computations: Federal Highway Administration Publication FHWA-IP-89-027, 187 p.

Shearman, J.O., Kirby, W.H., Schneider, V.R., and Flippo, H.N., 1986, Bridge waterways analysis model; research report: Federal Highway Administration Publication FHWA-RD-86-108, 112 p.

Talbot, A.N., 1887, The determination of water-way for bridges and culverts.

U.S. Department of Transportation, 1993, Stream stability and scour at highway bridges, Participant Workbook: Federal Highway Administration Publication FHWA HI-91-011.

U.S. Geological Survey, 1971, Andover, Vermont 7.5 Minute Series quadrangle map: U.S. Geological Survey Topographic Maps, Scale $1: 24,000$.

U.S. Geological Survey, 1972, Chester, Vermont 7.5 Minute Series quadrangle map: U.S. Geological Survey Topographic Maps, Scale $1: 24,000$. 


\section{APPENDIX A: \\ WSPRO INPUT FILE}




\section{WSPRO INPUT FILE}

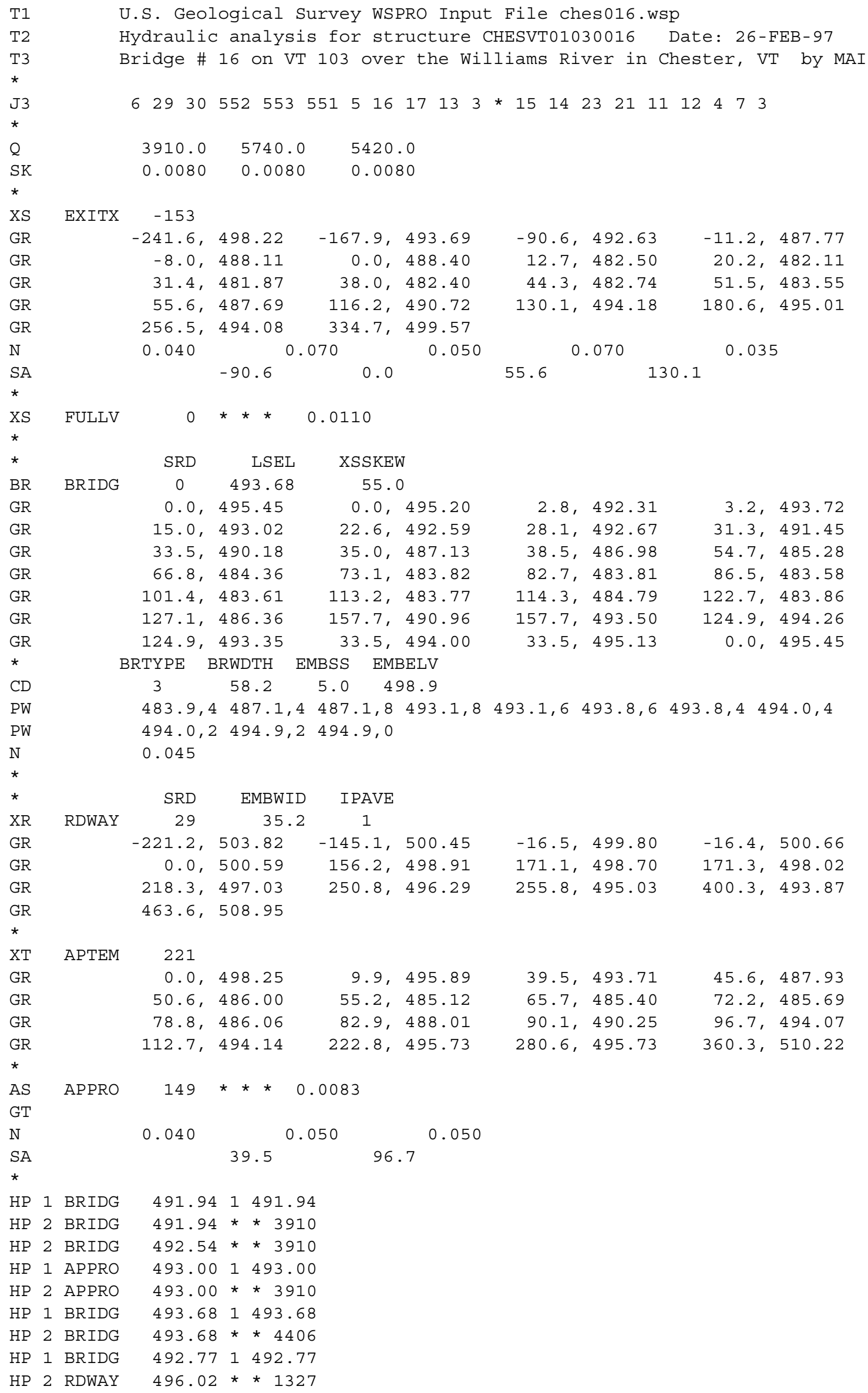




\section{APPENDIX B: \\ WSPRO OUTPUT FILE}




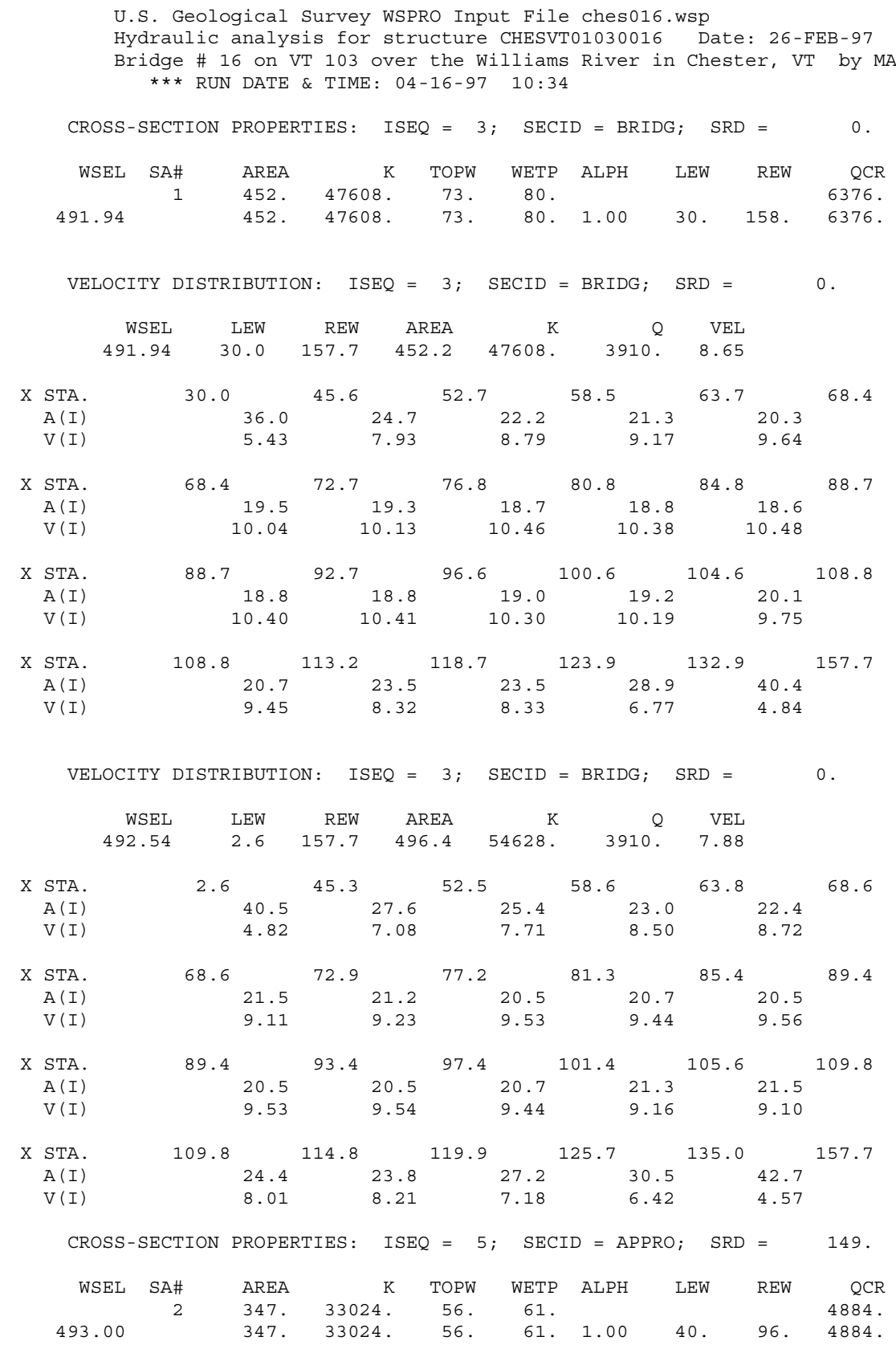

VELOCITY DISTRIBUTION $:$ ISEQ $=5 ; \quad \operatorname{SECID}=$ APPRO $; \quad$ SRD $=149$.

\begin{tabular}{|c|c|c|c|c|c|c|c|c|}
\hline & & WSEL & LEW & REW & A & Q & VEL & \\
\hline & & 493.00 & 39.6 & 95.9 & 33024 . & 3910 . & 11.28 & \\
\hline $\mathrm{X}$ & STA. & & 39.6 & 47.5 & 50.4 & 52.5 & 54.5 & 56.2 \\
\hline & $A(I)$ & & 28.5 & 19.8 & 16.7 & 15.8 & 14.8 & \\
\hline & $V(I)$ & & 6.85 & 9.86 & 11.69 & 12.41 & 13.21 & \\
\hline $\mathrm{X}$ & STA. & & 56.2 & 58.0 & 59.7 & 61.4 & 63.2 & 64.9 \\
\hline & $A(I)$ & & 14.9 & 14.5 & 14.2 & 14.5 & 14.4 & \\
\hline & $V(I)$ & & 13.15 & 13.48 & 13.77 & 13.53 & 13.60 & \\
\hline $\mathrm{X}$ & STA. & & 64.9 & 66.6 & 68.5 & 70.3 & 72.2 & 74.2 \\
\hline & $A(I)$ & & 14.4 & 14.7 & 15.0 & 15.0 & 15.7 & \\
\hline & $V(I)$ & & 13.61 & 13.32 & 13.04 & 13.04 & 12.44 & \\
\hline $\mathrm{X}$ & STA. & & 74.2 & 76.2 & 78.5 & 81.1 & 85.0 & 95.9 \\
\hline & $A(I)$ & & 15.8 & 17.0 & 18.8 & 21.5 & 30.9 & \\
\hline & $V(I)$ & & 12.38 & 11.52 & 10.40 & 9.07 & 6.34 & \\
\hline
\end{tabular}




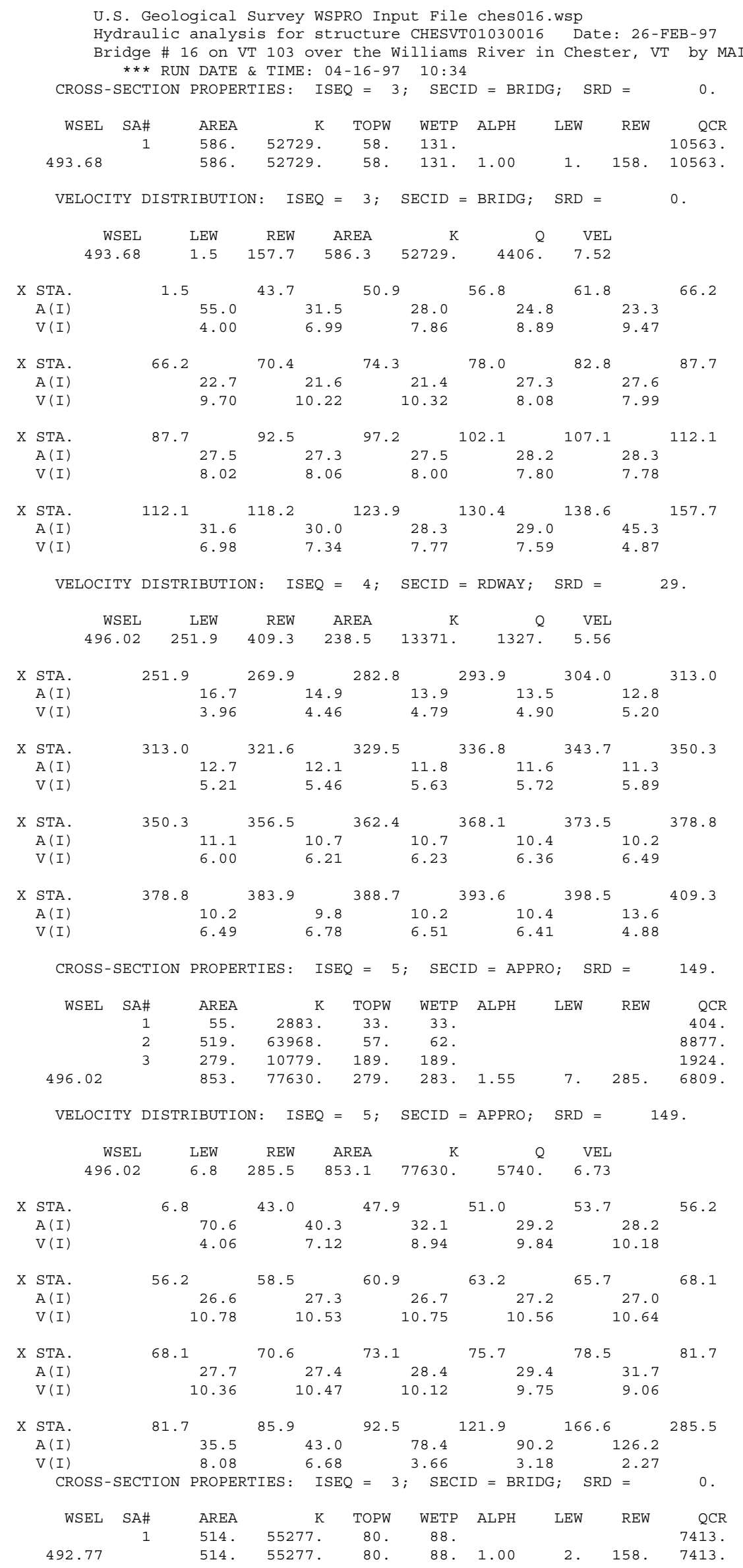


WSPRO OUTPUT FILE (continued)

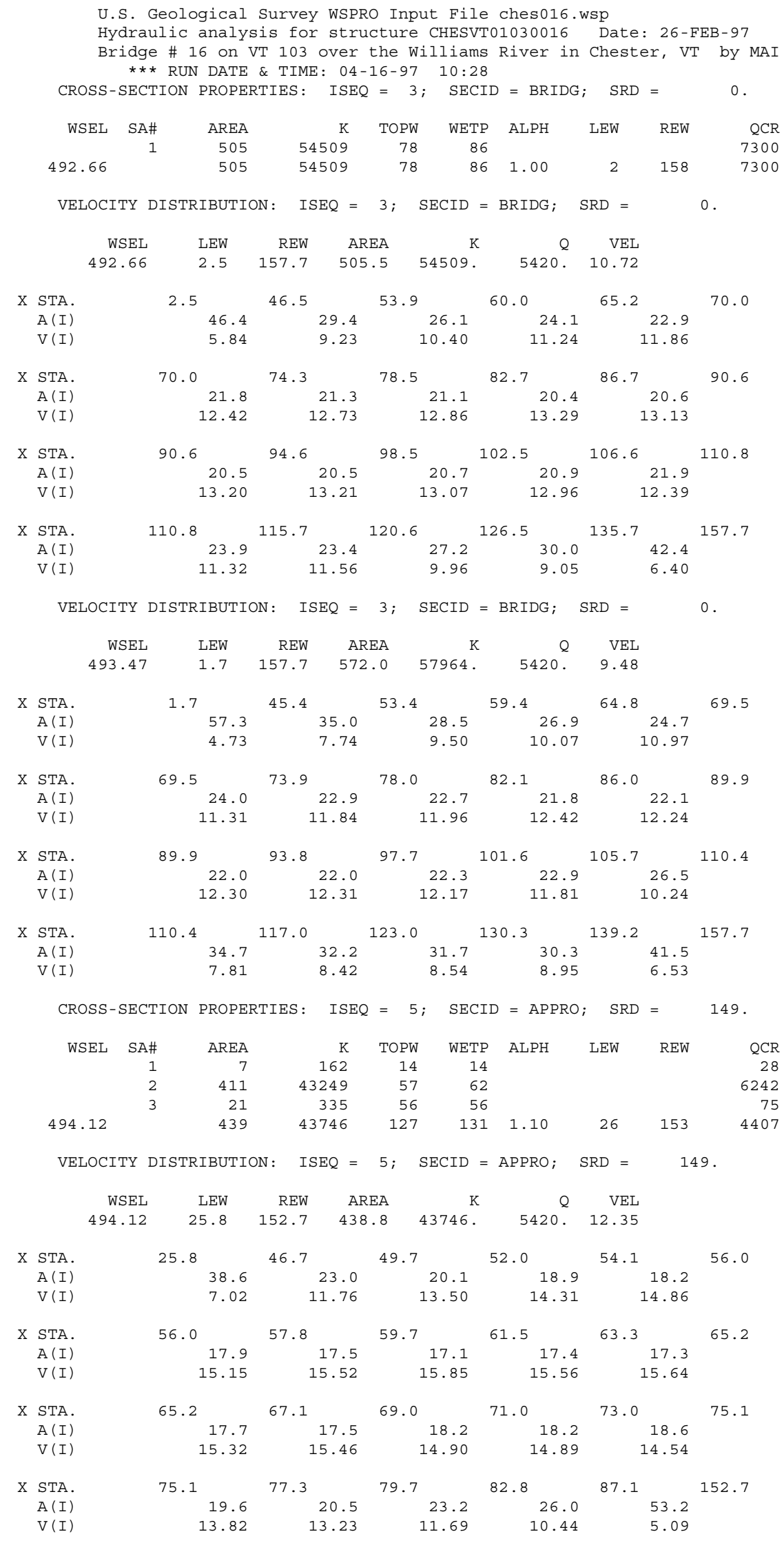


WSPRO OUTPUT FILE (continued)

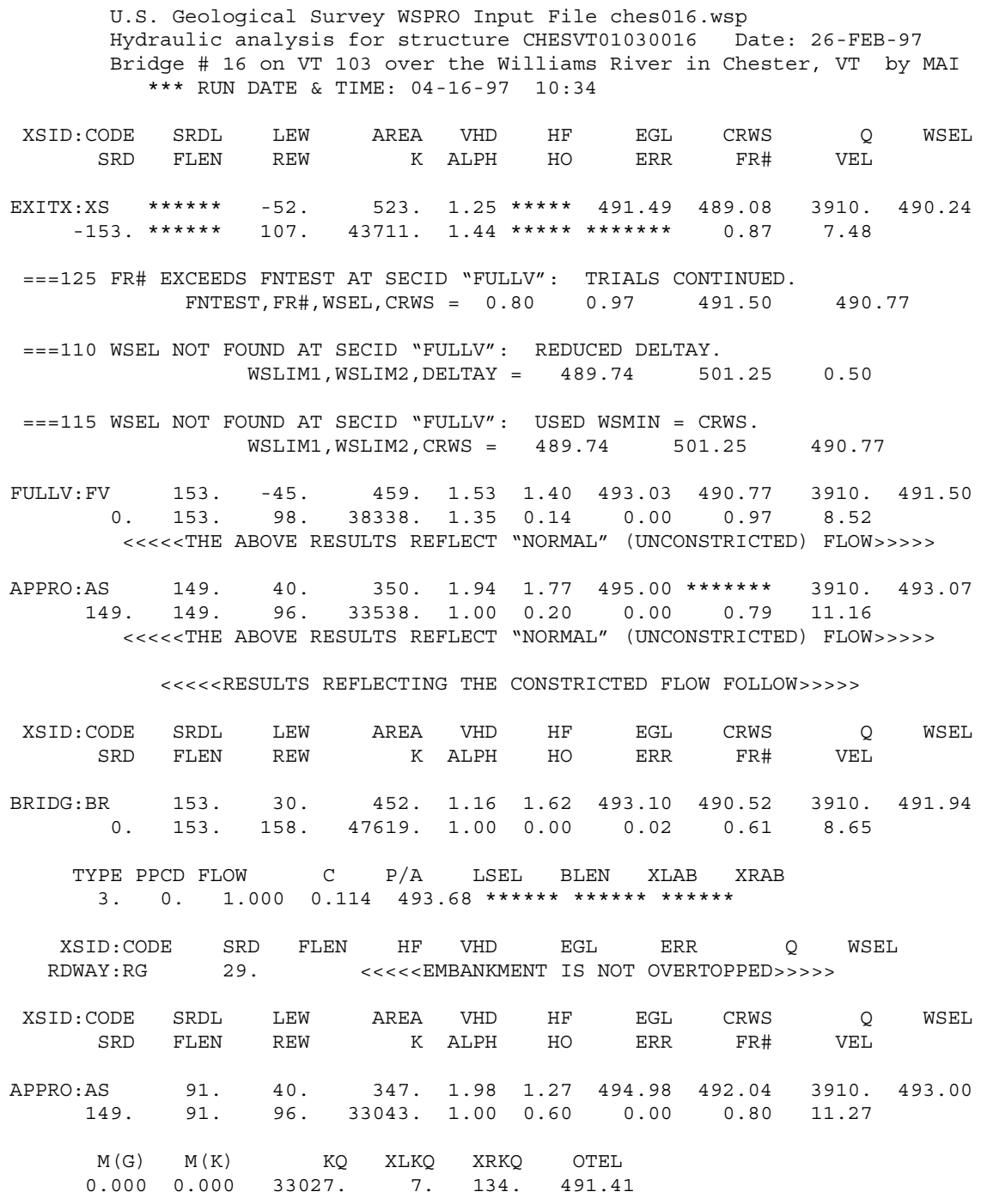

FIRST USER DEFINED TABLE.

\begin{tabular}{|c|c|c|c|c|c|c|c|c|}
\hline XSID : CODE & SRD & LEW & REW & $Q$ & K & AREA & VEL & WSEL \\
\hline EXITX:XS & -153. & -52 & 107. & 3910. & 43711 . & 523. & 7.48 & 490.24 \\
\hline FULLV : FV & 0 . & -45 & 98. & 3910. & 38338 . & 459. & 8.52 & 491.50 \\
\hline BRIDG : BR & 0 . & 30 . & 158. & 3910. & 47619 . & 452 . & 8.65 & 491.94 \\
\hline RDWAY : RG & \multicolumn{3}{|c|}{ 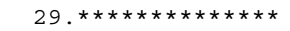 } & \multicolumn{3}{|c|}{ 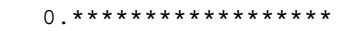 } & \multicolumn{2}{|c|}{$1.00 * * * * * * * *$} \\
\hline APPRO: AS & 149. & 40 & 96. & 3910. & 33043. & 347. & 11.27 & 493.00 \\
\hline XSID : CODE & XLKQ & XRKQ & & & & & & \\
\hline APPRO : AS & 7. & 134. & $3302^{\prime}$ & & & & & \\
\hline
\end{tabular}

SECOND USER DEFINED TABLE.

\begin{tabular}{|c|c|c|c|c|c|c|c|c|c|}
\hline XSID : CODE & CRWS & FR\# & YMIN & YMAX & $\mathrm{HF}$ & $\mathrm{HO}$ & VHD & EGL & WSEL \\
\hline EXITX:XS & 489.08 & 0.87 & 481.87 & 499.57 * & $\star * \star * \star * \star *$ & $* \star * * *$ & 1.25 & 491.49 & 490.24 \\
\hline FULLV : FV & 490.77 & 0.97 & 483.55 & 501.25 & 1.40 & 0.14 & 1.53 & 493.03 & 491.50 \\
\hline BRIDG : BR & 490.52 & 0.61 & 483.58 & 495.45 & 1.62 & 0.00 & 1.16 & 493.10 & 491.94 \\
\hline RDWAY : RG & 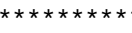 & $* * * *$ & 493.87 & $508.95 *$ & $* * * *$ & * * & $\star \star * * *$ & $\star \star \star *$ & 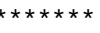 \\
\hline APPRO: AS & 492.04 & 0.80 & 484.52 & 509.62 & 1.27 & 0.60 & 1.98 & 494.98 & 493.00 \\
\hline
\end{tabular}


WSPRO OUTPUT FILE (continued)

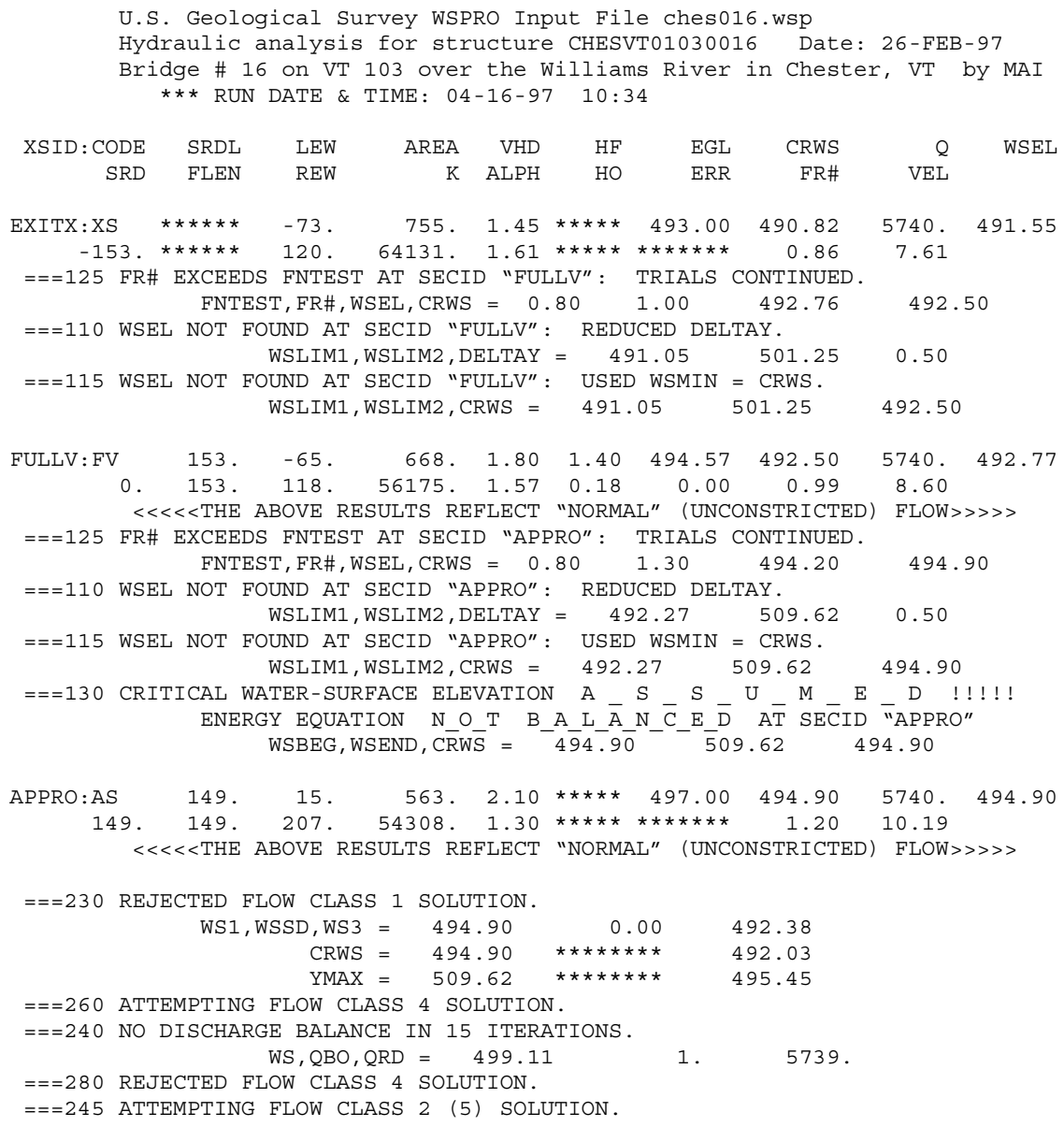


WSPRO OUTPUT FILE (continued)

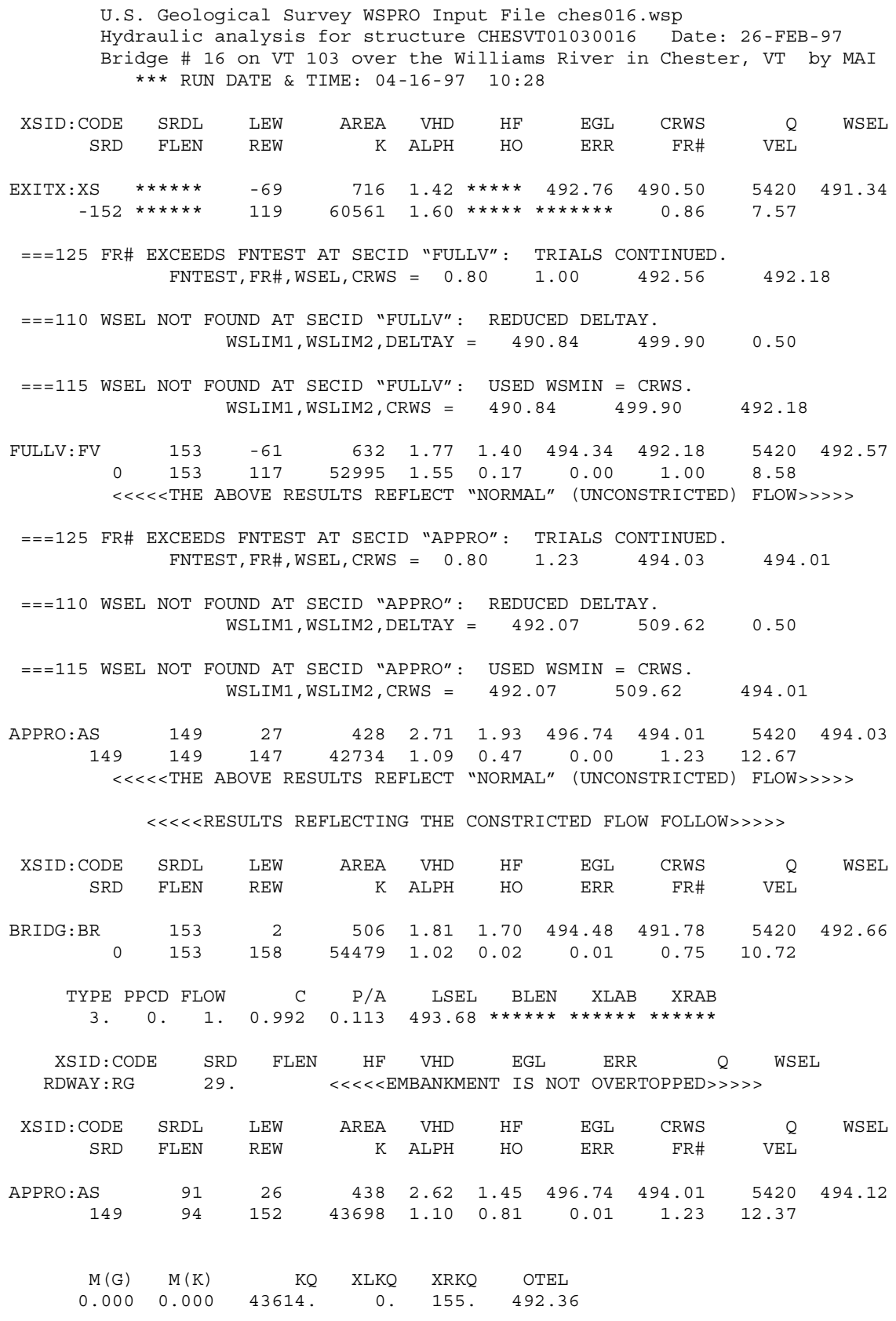

FIRST USER DEFINED TABLE.

\begin{tabular}{|c|c|c|c|c|c|c|c|c|}
\hline XSID : CODE & SRD & LEW & REW & Q & K & AREA & VEL & WSEL \\
\hline EXITX:XS & -153. & -70. & 119. & 5420 . & 60561 & 716. & 7.57 & 491.34 \\
\hline FULLV : FV & 0 . & -62. & 117. & 5420 . & 52995. & 632. & 8.58 & 492.57 \\
\hline BRIDG : BR & 0 . & 2 . & 158. & 5420. & 54479 . & 506. & 10.72 & 492.66 \\
\hline RDWAY : RG & \multicolumn{3}{|c|}{ 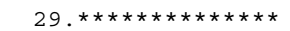 } & \multicolumn{3}{|c|}{$0 . * * * * * * * * * * * * * * * * * *$} & \multicolumn{2}{|c|}{$1.00 * \star \star * * * * *$} \\
\hline APPRO : AS & 149 . & 26. & 152. & 5420 . & 43698 & 438. & 12.37 & 494.12 \\
\hline XSID : CODE & XLKQ & XRKQ & & & & & & \\
\hline APPRO: AS & 0 . & 155. & 43614 & & & & & \\
\hline
\end{tabular}

SECOND USER DEFINED TABLE.

\begin{tabular}{|c|c|c|c|c|c|c|c|c|c|}
\hline XSID: CODE & CRWS & FR\# & YMIN & YMAX & $\mathrm{HF}$ & $\mathrm{HO}$ & VHD & EGL & WSEI \\
\hline EXITX:XS & 490.50 & 0.86 & 481.87 & 498.22 * & $* * \star * * * *$ & $* \star \star \star *$ & 1.42 & 492.76 & 491. \\
\hline FULLV : FV & 492.18 & 1.00 & 483.55 & 499.90 & 1.40 & 0.17 & 1.77 & 494.34 & 492 \\
\hline BRIDG : BR & 491.78 & 0.75 & 483.58 & 495.45 & 1.70 & 0.02 & 1.81 & 494.48 & 492 \\
\hline RDWAY : RG & $\star \star \star \star \star \star \star * \star * *$ & $\star * \star * *$ & 495.03 & $508.95 *$ & $* \star \star \star \star \star *$ & 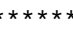 & 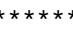 & $\star \star \star \star$ & 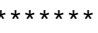 \\
\hline APPRO: AS & 494.01 & 1.23 & 484.52 & 509.62 & 1.45 & 0.81 & 2.62 & 496.74 & 494 \\
\hline
\end{tabular}




\section{APPENDIX C:}

\section{BED-MATERIAL PARTICLE-SIZE DISTRIBUTION}




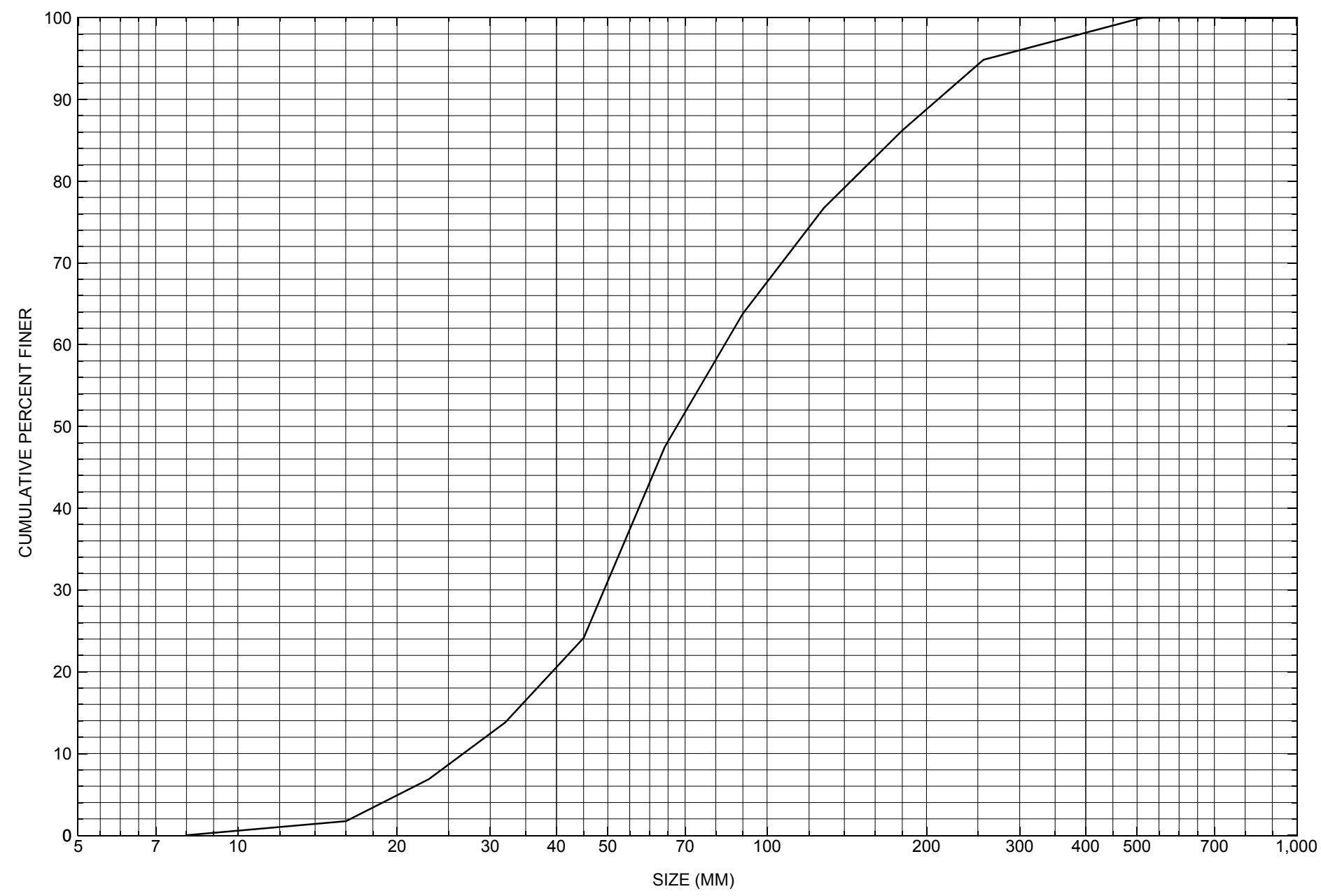

Appendix C. Bed material particle-size distribution for a pebble count in the channel approach of structure CHESVT01030016, in Chester, Vermont. 


\section{APPENDIX D: \\ HISTORICAL DATA FORM}




\section{Structure Number CHESVT01030016}

\section{General Location Descriptive}

Data collected by (First Initial, Full last name) $\mathbf{E}$. BOEHMLER

Date $(M M / D D / Y Y) \_\mathbf{0 3} / \underline{13} / \underline{95}$

Highway District Number (I - 2; nn) $\mathbf{0 3}$

Town (FIPS place code; I - 4; nnnnn) 13675

Waterway (I - 6) WILLIAMS RIVER

Route Number VT103

Topographic Map Chester

Latitude (I - 16; nnnn.n) $\mathbf{4 3 2 0 7}$
County (FIPS county code; I - 3; nnn)

Mile marker (I - 11; nnn.nnn) $\mathbf{0 0 9 5 6 0}$

Road Name (I - 7): -

Vicinity (I - 9) 1.7 MI N JCT. VT.10

Hydrologic Unit Code:

Longitude (i - 17; nnnnn.n) $\mathbf{7 2 3 7 4}$

\section{Select Federal Inventory Codes}

FHWA Structure Number $(I$ - 8) $\mathbf{2 0 0 0 2 5 0 0 1 6 1 4 0 7}$

Maintenance responsibility $(I-21 ; n n) \quad 01$

Year built (I - 27; YYYY) 1962

Average daily traffic, ADT (I - 29; nnnnnn) $\mathbf{0 0 4 4 7 0}$

Year of ADT (I - 30; YY) $\mathbf{9 2}$

Opening skew to Roadway $(I-34 ; n n) \quad 55$

Operational status $(I-41 ; X) \mathbf{A}$

Structure type (I - 43; nnn) $\mathbf{3 0 2}$

Approach span structure type $(I-44 ; n n n) \quad \mathbf{0 0 0}$

Number of spans (I - 45; nnn) $\underline{\mathbf{0 0 3}}$

Number of approach spans (I - 46; nnnn) $\mathbf{0 0 0 0}$

Comments:

The structural inspection report of 9/22/93 indicates the structure is a three span, rolled steel beam type bridge. The left abutment wall and its wingwalls are in good condition with the exception of some minor concrete cracking and scaling. Both piers are solid shaft type piers with some minor areas of concrete staining and cracking. The right abutment wall and its wingwalls are in good condition. The channel is straight and passes entirely through the middle span. There is some minor streambank erosion noted. Both abutment walls are protected by stone fill. The abutments are the spill-through type. Vegetation is noted on both banks up- and downstream of the bridge. 


\section{Bridge Hydrologic Data}

Is there hydrologic data available? $\underline{\mathbf{N}}$ if No, type ctrl-n $h \quad$ VTAOT Drainage area $\left(m i^{2}\right)$ : -

Terrain character: Hilly

Stream character \& type: -

Streambed material:

Discharge Data (cfs):

$$
\begin{aligned}
& Q_{2.33}- \\
& Q_{50}-
\end{aligned}
$$

Record flood date (MM / DD / YY):

Estimated Discharge (cfs): Ice conditions (Heavy, Moderate, Light) : Moderate

$$
\begin{aligned}
& Q_{25}- \\
& Q_{500}-
\end{aligned}
$$

Water surface elevation $(f t):-$

The stage increases to maximum highwater elevation (Rapidly, Not rapidly): Not rapidly The stream response is (Flashy, Not flashy): Not flashy

Describe any significant site conditions upstream or downstream that may influence the stream's stage: -

Watershed storage area (in percent):

The watershed storage area is: - (1-mainly at the headwaters; 2- uniformly distributed; 3-immediatly upstream oi the site)

Water Surface Elevation Estimates for Existing Structure:

\begin{tabular}{|l|l|l|l|l|l|}
\hline Peak discharge frequency & $Q_{2.33}$ & $Q_{10}$ & $Q_{25}$ & $Q_{50}$ & $Q_{100}$ \\
Water surface elevation (ft)) & - & - & - & - & - \\
Velocity (ft/sec) & - & - & - & - & - \\
\hline
\end{tabular}

Long term stream bed changes: -

Is the roadway overtopped below the $\mathrm{Q}_{100}$ ? (Yes, No, Unknown): $\mathbf{U} \quad$ Frequency: Relief Elevation $(f t)$ : Discharge over roadway at $Q_{100}\left(f^{3} / \mathrm{sec}\right)$ :

Are there other structures nearby? (Yes, No, Unknown): Upstream distance (miles): Town: If No or Unknown, type ctrl-n os Highway No. : Structure No. :Year Built:

Clear span $(f t): 34$ Clear Height $(f t)$ : Full Waterway $\left(f t^{2}\right): \mathbf{1 1 0 . 5}$ 
Downstream distance (miles): Town: Year Built:

Highway No. : Structure No. : Structure Type:

Clear span (ft): $\underline{35}$ Clear Height $(f t):$ Full Waterway $\left(\mathrm{ft}^{2}\right)$ : 140

Comments:

Some hydrologic data is found on the plans. A drainage area is given as 11,000 acres.

The area full opening is $\mathbf{4 5 0}$ square feet.

There is slight drift in the channel. The potential for ice blockage was noted as moderate.

\section{USGS Watershed Data}

Watershed Hydrographic Data

Drainage area $(D A) \underline{15.10} \mathrm{mi}^{2}$

Watershed storage (ST) $\quad \mathbf{0 . 0 2}$ $\mathrm{mi}^{2} \quad$ Lake and pond area 0.003 $\mathrm{mi}^{2}$

Bridge site elevation $820.0 \quad \mathrm{ft}$ $\%$

Main channel length 8.45 mi $10 \%$ channel length elevation 940.0 $\mathrm{ft} \quad 85 \%$ channel length elevation

1840.0 $\mathrm{ft}$

Main channel slope $(S)$

(S) 142.01 $\mathrm{ft} / \mathrm{mi}$

Watershed Precipitation Data

Average site precipitation in Average headwater precipitation in

Maximum 2yr-24hr precipitation event $(124,2)$ in

Average seasonal snowfall (Sn) $\mathrm{ft}$ 


\section{Bridge Plan Data}

Are plans available? $\underline{\mathbf{Y}}$ If no, type ctrl-n pl Date issued for construction (MM/YYYY): $\underline{\mathbf{0 8}} / \underline{\mathbf{1 9 6 0}}$

Project Number F 025 1(8)

Minimum channel bed elevation: $\mathbf{8 1 5}$

Low superstructure elevation: USLAB $\underline{\mathbf{8 2 7 . 0 1}}$ DSLAB $\underline{\mathbf{8 2 6 . 0 1}}$ USRAB $\underline{\mathbf{8 2 5 . 2 5}}$ DSRAB $\underline{\mathbf{8 2 4 . 0 5}}$

Benchmark location description:

No benchmark information is provided on the plans. Taken from the plans, on the right abutment at the downstream end there are 3 interconnected, step like, concrete posts forming the end of the guardrail.

The indicated elevation on the lowest of the 3 steps, at the very end of the post toward the right bank is 830.21. The datum is unknown but probably arbitrary.

Reference Point (MSL, Arbitrary, Other): Arbitrary $\quad$ Datum (NAD27, NAD83, Other): Arbitrary

Foundation Type: 1 (1-Spreadfooting; 2-Pile; 3- Gravity; 4-Unknown)

If 1: Footing Thickness $\mathbf{2 . 0} \quad$ Footing bottom elevation: $\underline{\mathbf{8 0 9 . 0}}$

If 2: Pile Type: ___ (1-Wood; 2-Steel or metal; 3-Concrete) Approximate pile driven length:

If 3: Footing bottom elevation:

Is boring information available? $\underline{\mathbf{Y}}$ If no, type ctrl-n bi Number of borings taken: 14

Foundation Material Type: 1 (1-regolith, 2-bedrock, 3-unknown)

Briefly describe material at foundation bottom elevation or around piles:

The pier footings are set in a compact to wet, loose brown sand and coarse gravel and some cobbles. The left abutment is shown in a mica schist bedrock at least at the upstream end. The right abutment is probably set in a wet, loose, brown, coarse sand, gravel, and cobbles.

Comments:

The bottom of footing elevation shown above is that for the bottom of each pier. The bottom of each abutment footing is depicted at elev. 815.0 on the plans. The abutment footings are shown protected by the spill-through abutment stone fill on the plans. These plans are listed under the last project number which is "F025-1(8)". Opposite side of previous BM is 832.57. The low superstructure elevation for the piers are: pier 1(left) upstream end 826.70(left), 825.59(right) and downstream end 825.68(left), 824.55(right); pier 2(right) upstream end 824.75(left), 825.67(right) and downstream end 823.90(left), 824.81(right). The pier footing is 2 feet thick. 


\section{Cross-sectional Data}

Is cross-sectional data available? Yes If no, type ctrl-n xs

Source (FEMA, VTAOT, Other)? FEMA Comments:

The elevations and stations are measured in feet.

\begin{tabular}{|l|l|l|l|l|l|l|l|l|l|l|l|}
\hline Station & 432 & 464 & 468 & 524 & 562 & 566 & 598 & - & - & - & - \\
\hline Feature & LAB & - & - & - & - & - & RAB & - & - & - & - \\
\hline $\begin{array}{l}\text { Low cord } \\
\text { elevation }\end{array}$ & $\mathbf{8 2 6 . 1}$ & $\mathbf{8 2 6 . 1}$ & $\mathbf{8 2 6 . 1}$ & $\mathbf{8 2 6 . 1}$ & $\mathbf{8 2 6 . 1}$ & $\mathbf{8 2 6 . 1}$ & $\mathbf{8 2 6 . 1}$ & - & - & - & - \\
\hline $\begin{array}{l}\text { Bed } \\
\text { elevation }\end{array}$ & $\mathbf{8 2 2 . 6}$ & $\mathbf{8 1 9}$ & $\mathbf{8 1 6 . 1}$ & $\mathbf{8 1 4 . 8}$ & $\mathbf{8 1 6 . 1}$ & $\mathbf{8 1 7 . 5}$ & $\mathbf{8 2 1 . 1}$ & - & - & - & - \\
\hline $\begin{array}{l}\text { Low cord to } \\
\text { bed length }\end{array}$ & $\mathbf{3 . 5}$ & $\mathbf{7 . 1}$ & $\mathbf{1 0}$ & $\mathbf{1 1 . 3}$ & $\mathbf{1 0}$ & $\mathbf{8 . 6}$ & $\mathbf{5}$ & - & - & - & - \\
\hline Station & - & - & - & - & - & - & - & - & - & - & - \\
\hline Feature & - & - & - & - & - & - & - & - & - & - & \\
\hline $\begin{array}{l}\text { Low cord } \\
\text { elevation }\end{array}$ & - & - & - & - & - & - & - & - & - & - & - \\
\hline $\begin{array}{l}\text { Bed } \\
\text { elevation }\end{array}$ & - & - & - & - & - & - & - & - & - & - & - \\
\hline $\begin{array}{l}\text { Low cord to } \\
\text { bed length }\end{array}$ & - & - & - & - & - & - & - & - & - & - & - \\
\hline
\end{tabular}

Source (FEMA, VTAOT, Other)?

Comments: -

\begin{tabular}{|l|l|l|l|l|l|l|l|l|l|l|l|}
\hline Station & - & - & - & - & - & - & - & - & - & - & - \\
\hline Feature & - & - & - & - & - & - & - & - & - & - & - \\
\hline $\begin{array}{l}\text { Low cord } \\
\text { elevation }\end{array}$ & - & - & - & - & - & - & - & - & - & - & - \\
\hline $\begin{array}{l}\text { Bed } \\
\text { elevation }\end{array}$ & - & - & - & - & - & - & - & - & - & - & - \\
\hline $\begin{array}{l}\text { Low cord to } \\
\text { bed length }\end{array}$ & - & - & - & - & - & - & - & - & - & - & - \\
\hline Station & - & - & - & - & - & - & - & - & - & - & - \\
\hline Feature & - & - & - & - & - & - & - & - & - & - & - \\
\hline $\begin{array}{l}\text { Low cord } \\
\text { elevation }\end{array}$ & - & - & - & - & - & - & - & - & - & - & - \\
\hline $\begin{array}{l}\text { Bed } \\
\text { levation }\end{array}$ & - & - & - & - & - & - & - & - & - & - & - \\
\hline $\begin{array}{l}\text { Low cord to } \\
\text { bed length }\end{array}$ & - & - & - & - & - & - & - & - & - & - & - \\
\hline
\end{tabular}




\section{APPENDIX E: \\ LEVEL I DATA FORM}


U. S. Geological Survey

Bridge Field Data Collection and Processing Form

Qa/Qc Check by: EW

Date: $9 / 23 / 96$

Computerized by: $\mathrm{EW}$ Date: $9 / \mathbf{2 4 / 9 6}$

\section{Structure Number CHESVT01030016}

Reviewd by: MAI Date: $\underline{\mathbf{5} / \mathbf{2 9} / \mathbf{9 7}}$

\section{A. General Location Descriptive}

1. Data collected by (First Initial, Full last name) R. HAMMOND

Date $(M M / D D / Y Y) 09 / 16 / 1996$

2. Highway District Number $\mathbf{0 3}$

County WINDSOR (027)

Waterway ( $($ - 6) WILLIAMS RIVER

Route Number VT 103

Mile marker 009560

Town CHESTER (13675)

Road Name -

Hydrologic Unit Code: $\mathbf{0 1 0 8 0 1 0 7}$

3. Descriptive comments:

Located 1.7 miles north of the junction with Vermont 10, and at the junction with TH09 (Smokeshire road). A local resident said the 1973 flood flow overtopped Smokeshire road, and none went over Vermont 103. All of the flood water went through the bridge.

\section{B. Bridge Deck Observations}
4. Surface cover... LBUS 4
RBUS 4
LBDS 4
RBDS 6
Overall 6

(2b us, ds,lb,rb: 1- Urban; 2- Suburban; 3- Row crops; 4- Pasture; 5- Shrub- and brushland; 6- Forest; 7- Wetland)
5. Ambient water surface... US 2
UB 2 DS 2
(1- pool; 2- riffle)

6. Bridge structure type 2 (1- single span; 2- multiple span; 3- single arch; 4- multiple arch; 5-cylindrical culvert; 6- box culvert; or 7- other)
7. Bridge length 162
(feet)
Span length 87
(feet)
Bridge width $\underline{35.2}$ (feet)

\section{Road approach to bridge:}
8. LB 0 RB 0
( 0 even, 1- lower, 2- higher)
9. $\mathrm{LB}$
RB 1
(1- Paved, 2- Not paved)

10. Embankment slope (run / rise in feet / foot):

US left --:1

US right --:1

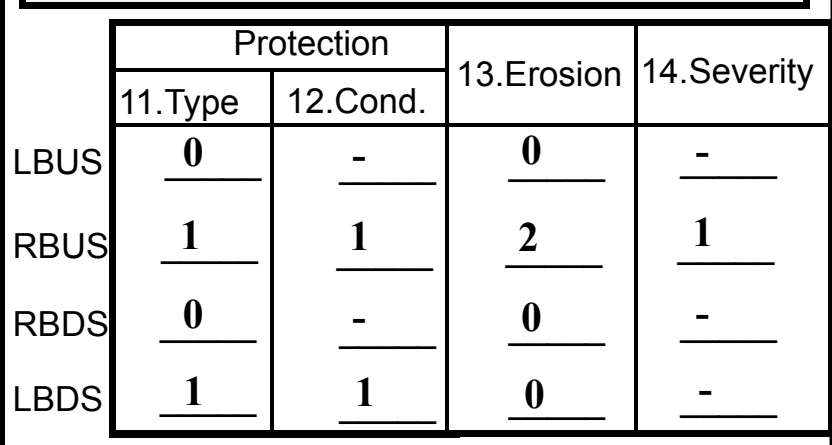

Bank protection types: 0- none; 1- < 12 inches;

2- < 36 inches; 3- < 48 inches;

4- < 60 inches; 5- wall / artificial levee

Bank protection conditions: 1- good; 2- slumped;

3- eroded; 4- failed

Erosion: 0 - none; 1- channel erosion; 2-

road wash; 3- both; 4- other

Erosion Severity: 0 - none; 1- slight; 2- moderate;

\section{Channel approach to bridge (BF):}

15. Angle of approach: $\mathbf{0}$

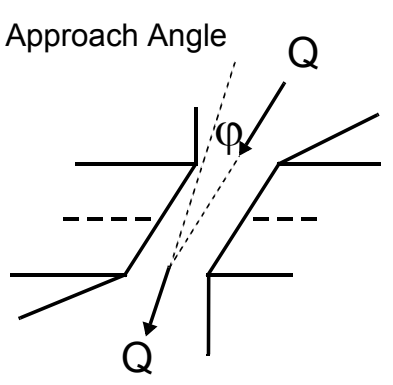

17. Channel impact zone 1 :

Where? LB $(L B, R B)$

Range? 300 feet US

Channel impact zone 2:

Where? RB (LB, RB)

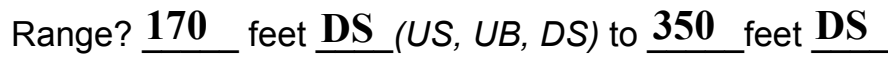

Impact Severity: 0- none to very slight; 1- Slight; 2- Moderate; 3- Severe
16. Bridge skew: $\mathbf{5 5}$ Bridge Skew Angle

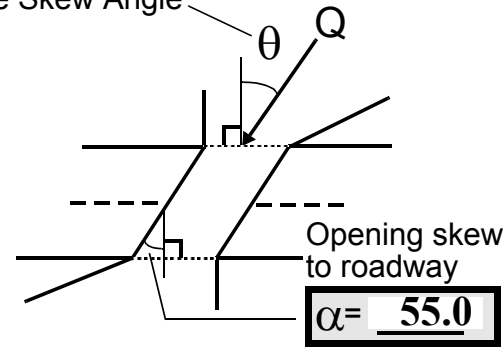

\section{Exist? $\underline{\mathbf{Y}}(\mathrm{Y}$ or $N)$}

Severity 1

(US, UB, DS) to $\underline{\mathbf{2 0 0}}$ feet $\underline{\mathbf{U S}}$

Exist? $\mathbf{Y}(\mathrm{Y}$ or $N)$

Severity 1 
18. Bridge Type: $\mathbf{3}$

1a- Vertical abutments with wingwalls

1 b- Vertical abutments without wingwalls

2- Vertical abutments and wingwalls, sloping embankment Wingwalls perpendicular to abut. face

3- Spill through abutments

4- Sloping embankment, vertical wingwalls and abutments

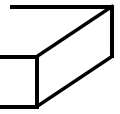

Wingwall angle less than $90^{\circ}$.
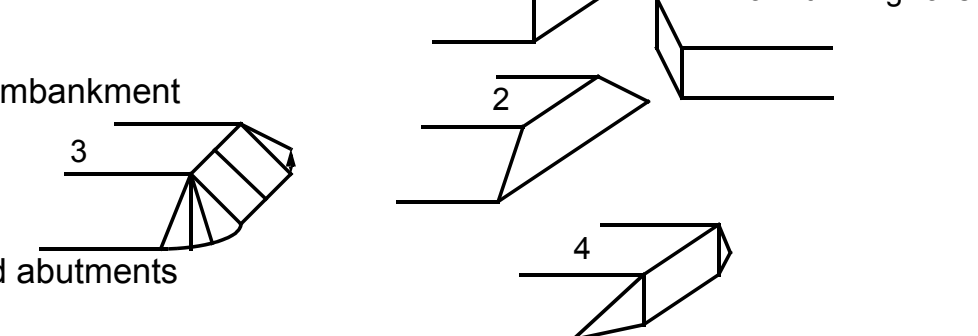

19. Bridge Deck Comments (surface cover variations, measured bridge and span lengths, bridge type variations, approach overflow width, etc.)

\#4: There are lawns surrounding houses on all banks (upstream and downstream) with woods behind, except on the downstream left bank there is pasture beyond the house.

\#7: The bridge dimensions are from the VTAOT database. The measured dimensions are: US bridge length = $\mathbf{1 8 8 . 8}$ feet; span $=\mathbf{1 5 5 . 7}$ feet; and deck width from the inside edges of curbs $=\mathbf{3 0 . 4}$ feet; DS bridge length $=$ 189.6 feet; span $=\mathbf{1 5 7 . 6}$ feet; and deck width between outside edges of cubs $=34.8$ feet.

The lengths underneath the bridge, measured perpendicular to flow between the left abutment and pier 1 is 16 feet; between pier 1 and pier 2 is 49 feet; and between pier 2 and the right abutment is 16 feet. The lengths underneath the bridge, measured parallel to bridge deck between the left abutment and pier 1 is 30 feet; between pier 1 and pier 2 is 89 feet; and between pier 2 and the right abutment is 30 feet. \#18: There is type 3 stone fill (less than 48 inches diameter) between the piers and abutments forming a spillthrough embankment.

\section{Upstream Channel Assessment}

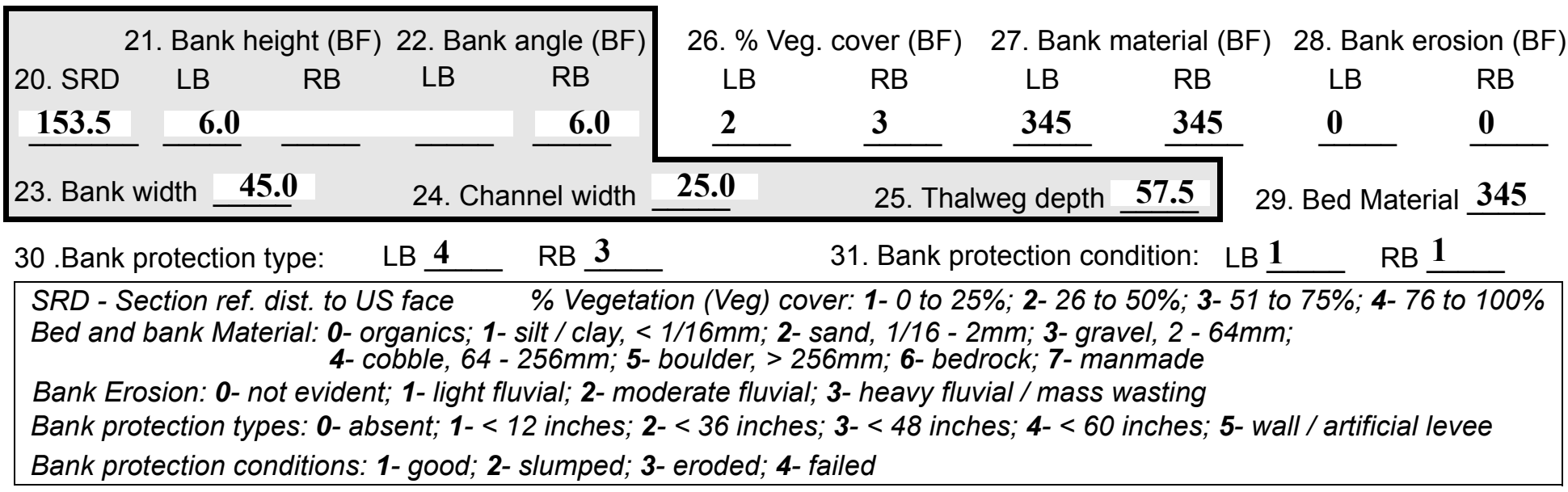

32. Comments (bank material variation, minor inflows, protection extent, etc.):

\#27: The above values were determined from the natural bank, approximately 450 feet upstream from bridge.

\#29: Bedrock exists across entire channel approximately 450 feet upstream.

\#30: The left bank protection extends from 400 feet upstream to 40 feet upstream. The protection consists of large boulders along the bank to protect road which is parallel to the river. The right bank protection, which is an old stone wall, extends from 400 feet upstream to 15 feet upstream. Boulders also have been placed along the right bank. 

feet US (US, UB) to $\underline{\mathbf{1 4 5}}$ feet $\underline{\mathrm{DS}}$ (US, UB, DS) positioned $\underline{\mathbf{0}}$ $\%$ LB to $\mathbf{5 0}$ $\% \mathrm{RB}$

37. Material: $\mathbf{4 3 5}$

38. Point or side bar comments (Circle Point or Side) Note additional bars, material variation, status, etc.):

This side bar is adjacent to pier 1 , along the left bank.

39. Is a cut-bank present? $\mathbf{Y}$ ( $Y$ or if $N$ type ctrl-n $c b)$ 40. Where? $\underline{\mathbf{L B}}$ (LB or RB)

41. Mid-bank distance: $\mathbf{4 3 0}$ 42. Cut bank extent: 450

43. Bank damage: 1 (1- eroded and/or creep; 2- slip failure; 3- block failure)

44. Cut bank comments (eg. additional cut banks, protection condition, etc.):

The cut-bank is just downstream of bedrock bed, and is probably a result of turbulence caused by flow over bedrock.

\section{Is channel scour present? $\mathbf{Y}$ ( $Y$ or if $N$ type ctrl-n cs) $\quad$ 46. Mid-scour distance: $\mathbf{4 5 0}$}

47. Scour dimensions: Length $\underline{\mathbf{1 5}}$ Width $\underline{\mathbf{1 0}}$ Depth : $\underline{\mathbf{2}}$ Position $\underline{\mathbf{4 5}} \%$ LB to $\underline{\mathbf{5 5}} \%$ RB

48. Scour comments (eg. additional scour areas, local scouring process, etc.):

Scour exists just below bedrock in channel.

49. Are there major confluences? $\mathbf{N}$

51. Confluence 1: Distance -

Confluence 2: Distance -

NO MAJOR CONFLUENCES
( $Y$ or if $N$ type ctrl-n $m c)$

52. Enters on -

Enters on ( $L B$ or $R B$ ) (LB or RB) (1-perennial; 2- ephemeral)

53. Type(1-perennial; 2- ephemeral)

Type -

\section{Under Bridge Channel Assessment}

55. Channel restraint (BF)? LB 2

\begin{tabular}{|cccc}
\hline \multicolumn{2}{|c|}{ 66. Height (BF) } & \multicolumn{2}{c}{57 Angle (BF) } \\
LB & RB & LB & RB \\
37.5 & & $\mathbf{0 . 5}$ & \\
\hline
\end{tabular}
(1- natural bank; 2- abutment; 3- artificial levee)

58. Bank width (BF) 59. Channel width (Amb) -

61. Material (BF)

LB RB

$\underline{2} \quad \underline{5}$
62. Erosion (BF)

LB RB

$5 \quad 0$

Bed and bank Material: 0- organics; 1- silt / clay, < 1/16mm; 2- sand, 1/16 - 2mm; 3- gravel, 2 - 64mm; 4- cobble, 64 - 256mm; 5- boulder, > 256mm; 6- bedrock; 7- manmade

Bank Erosion: 0- not evident; 1- light fluvial; 2- moderate fluvial; 3- heavy fluvial / mass wasting

64. Comments (bank material variation, minor inflows, protection extent, etc.):

435

The length of flow is 55 feet between the upstream and downstream bridge faces.

\#55: There is about 2-3 feet of concrete abutment exposed between top of placed stone and bridge seat. At the abutments there is $\mathbf{0 . 2}$ feet difference between the bridge seat and low cord. 
65. Debris and Ice Is there debris accumulation?

67. Debris Potential (1- Low; 2- Moderate; 3- High)

69. Is there evidence of ice build-up? 1 (Y or $N)$

70. Debris and Ice Comments:

1

There is severe scaring on the upstream side of a tree (8 inches in diameter) in the upstream left bank impact zone. There are trees leaning over the channel upstream.

\begin{tabular}{|l|c|c|c|c|c|c|c|c|}
\hline Abutments & $\begin{array}{c}\text { 71. Attack } \\
\angle \text { (BF) }\end{array}$ & $\begin{array}{c}\text { 72. Slope } \angle \\
\text { (Qmax) }\end{array}$ & $\begin{array}{c}\text { 73. Toe } \\
\text { loc. (BF) }\end{array}$ & $\begin{array}{c}\text { 74. Scour } \\
\text { Condition }\end{array}$ & $\begin{array}{c}75 . \text { Scour } \\
\text { depth }\end{array}$ & $\begin{array}{c}\text { 76. Exposure } \\
\text { depth }\end{array}$ & 77. Material & 78. Length \\
\hline LABUT & & $\mathbf{0}$ & $\mathbf{9 0}$ & $\mathbf{0}$ & $\mathbf{0}$ & - & - & $\mathbf{9 0 . 0}$ \\
\hline RABUT & $\mathbf{1}$ & $\mathbf{0}$ & $\mathbf{9 0}$ & & & $\mathbf{0}$ & $\mathbf{0}$ & $\mathbf{9 0 . 5}$ \\
\hline
\end{tabular}

Pushed: $L B$ or RB

Toe Location (Loc.): 0- even, 1- set back, 2- protrudes

Scour cond.: 0- not evident; 1- evident (comment); 2- footing exposed; 3-undermined footing; 4- piling exposed; 5- settled; 6- failed

Materials: 1- Concrete; 2- Stone masonry or drywall; 3- steel or metal; 4- wood

79. Abutment comments (eg. undermined penetration, unusual scour processes, debris, etc.):

$-$

1

\#71- \#77: The values above are based on the vertical concrete abutment. There is stone fill forming a spillthrough embankment between the abutments and piers, with a slope of 30 degrees.

80. Wingwalls:

$\begin{array}{llll} & & & \\ \text { Exist? Material? } & \text { Scour } & \text { Scour Exposure } & \text { Angle? Length? } \\ & \text { Condition? depth? depth? }\end{array}$

USLWW:

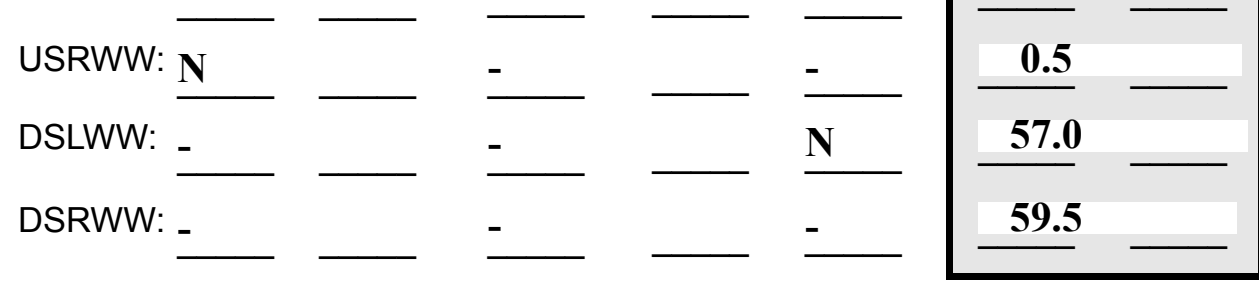

Wingwall materials: 1- Concrete; 2- Stone masonry or drywall; 3- steel or metal; 4- wood

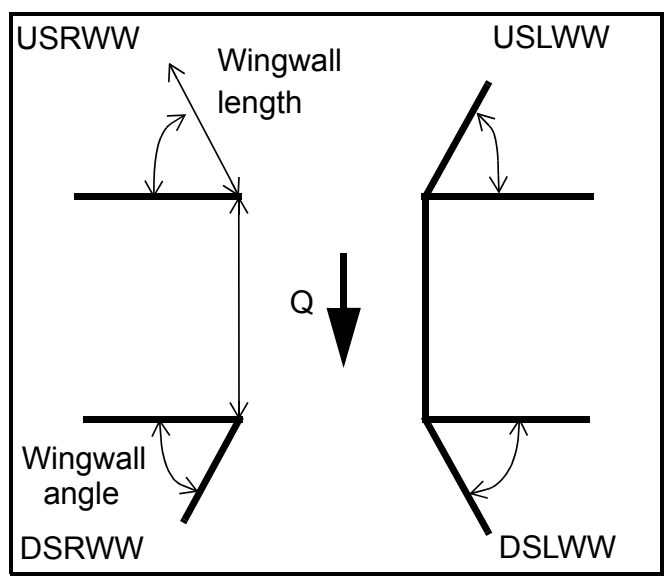

82. Bank / Bridge Protection:

\begin{tabular}{|l|l|l|l|l|l|l|l|c|}
\hline Location & USLWW & USRWW & LABUT & RABUT & LB & RB & DSLWW & DSRWW \\
\hline Type & - & - & $\mathbf{N}$ & - & - & - & $\mathbf{1}$ & $\mathbf{1}$ \\
\hline Condition & $\mathbf{N}$ & - & - & - & - & - & $\mathbf{1}$ & $\mathbf{1}$ \\
\hline Extent & - & - & - & - & - & $\mathbf{3}$ & $\mathbf{3}$ & - \\
\hline
\end{tabular}

Bank / Bridge protection types: 0- absent; 1- < 12 inches; 2- < 36 inches; 3- < 48 inches; 4- < 60 inches; 
83. Wingwall and protection comments (eg. undermined penetration, unusual scour processes, etc.):

-
-
-
-
-
-
-

\section{Piers:}

84. Are there piers? (Y or if $N$ type ctrl-n pr)

\begin{tabular}{|l|l|l|l|l|l|l|l|}
\hline \multirow{2}{*}{$\begin{array}{l}85 . \\
\text { Pier no. }\end{array}$} & \multicolumn{3}{|c|}{ width (w) feet } & \multicolumn{3}{c|}{ elevation (e) feet } \\
\cline { 2 - 8 } & w1 & w2 & w3 & e@w1 & e@w2 & e@w3 \\
\hline Pier 1 & - & - & - & - & - & - \\
\hline Pier 2 & - & $\mathbf{4}$ & $\mathbf{4}$ & - & $\mathbf{4 9 4 . 0 0}$ & $\mathbf{4 8 7 . 1 3}$ \\
\hline Pier 3 & - & $\mathbf{4}$ & $\mathbf{4}$ & - & $\mathbf{4 9 3 . 3 5}$ & $\mathbf{4 8 5 . 1 0}$ \\
\hline Pier 4 & - & - & - & - & - & - \\
\hline
\end{tabular}

\begin{tabular}{|l|l|l|l|l|}
\hline Level 1 Pier Descr. & \multicolumn{1}{|c|}{2} & \multicolumn{1}{|c|}{3} & 4 \\
\hline 86. Location (BF) & & L & MCR & \\
\hline 87. Type & & $\mathbf{1}$ & $\mathbf{1}$ & \\
\hline 88. Material & & $\mathbf{2}$ & $\mathbf{2}$ & \\
\hline 89. Shape & & $\mathbf{1}$ & $\mathbf{1}$ & \\
\hline 90. Inclined? & & $\mathbf{N}$ & $\mathbf{N}$ & \\
\hline 91. Attack $\angle$ (BF) & & $\mathbf{0}$ & $\mathbf{0}$ & \\
\hline 92. Pushed & & - & - & \\
\hline 93. Length (feet) & - & - & - & - \\
\hline 94. \# of piles & & - & - & \\
\hline 95. Cross-members & & $\mathbf{0}$ & $\mathbf{0}$ & \\
\hline 96. Scour Condition & & $\mathbf{0}$ & $\mathbf{0}$ & \\
\hline 97. Scour depth & $\mathbf{Y}$ & - & - & \\
\hline 98. Exposure depth & $\mathbf{M C}$ & - & - & \\
\hline
\end{tabular}

LFP, LTB, LB, MCL, MCM, MCR, RB, RTB, RFP

1- Solid pier, 2- column, 3- bent

1-Wood; 2-concrete; 3- metal; 4- stone

1- Round; 2- Square; 3- Pointed

Y-yes; $N$ - no

$L B$ or $R B$

0- none; 1- laterals; 2- diagonals; 3- both

0- not evident; 1- evident (comment);

2- footing exposed; 3- piling exposed;

4- undermined footing; 5- settled; 6- failed 
99. Pier comments (eg. undermined penetration, protection and protection extent, unusual scour processes, etc.):

100.

\section{E. Downstream Channel Assessment}

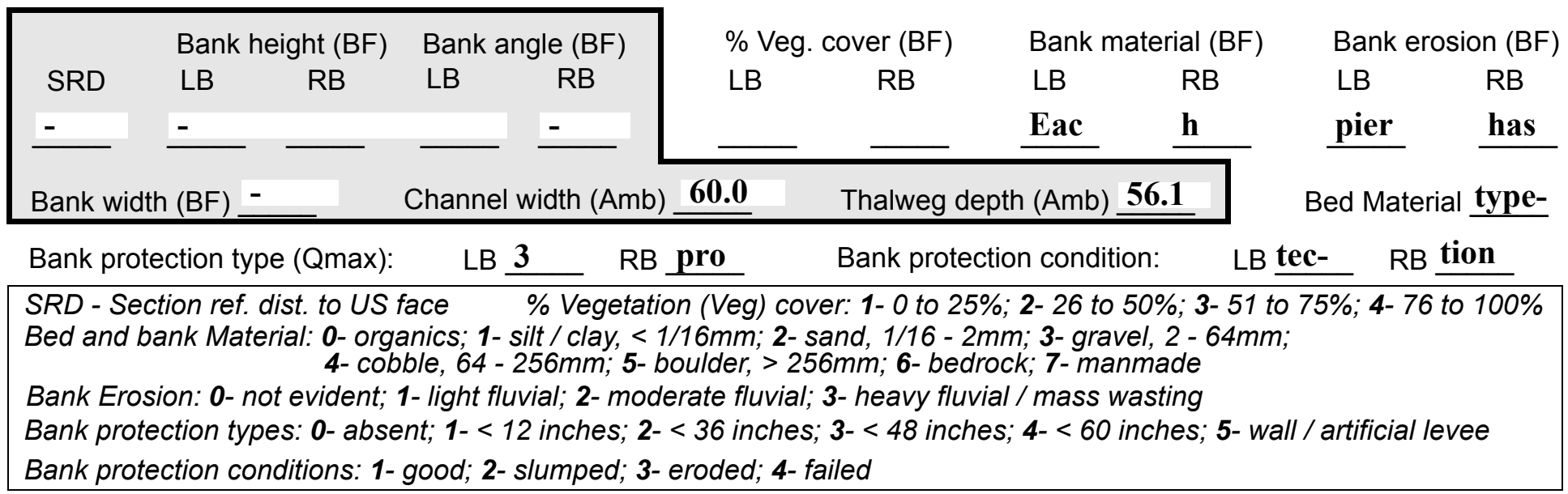

Comments (eg. bank material variation, minor inflows, protection extent, etc.):

surrounding the base.

101. Is a drop structure present? 0 (Y or $N$, if $N$ type ctrl-n ds) 102. Distance: ___ feet 103. Drop: -_ feet 104. Structure material: 435 (1- steel sheet pile; 2- wood pile; 3- concrete; 4- other) 105. Drop structure comments (eg. downstream scour depth):

3

3

1

1

The left bank protection extends from 35 feet under bridge to 190 feet downstream. There is an old rock wall/ pile to approximately 300 feet downstream. 
106. Point/Side bar present? Th (Y or N. if N type ctrl-n pb)Mid-bar distance: e Mid-bar width: right Point bar extent: $\underline{\text { bank feet pro }}$ (US, UB, DS) to tec- feet $\underline{\text { tio }}$ (US, UB, DS) positioned $\underline{\mathbf{n}} \%$ LB to ext $\%$ RB Material: en

Point or side bar comments (Circle Point or Side; note additional bars, material variation, status, etc.):

ds from 36 feet downstream to 145 feet downstream. There is an old rock wall/pile to 300 feet downstream.

Is a cut-bank present?

Cut bank extent: feet (Y or if $N$ type ctrl-n cb)

Where? (LB or $R B)$ feet (US, UB, DS)

Bank damage: (US, UB, DS) to (1- eroded and/or creep; 2- slip failure; 3- block failure)

Cut bank comments (eg. additional cut banks, protection condition, etc.): $\mathbf{N}$

$-$

\section{NO DROP STRUCTURE}

Is channel scour present? ( $Y$ or if $N$ type ctrl-n cs)

Mid-scour distance:

Scour dimensions: Length Width Depth: $\mathbf{N}$

Positioned $\%$ LB to $\%$ RB

Scour comments (eg. additional scour areas, local scouring process, etc.):

$-$

$-$

Are there major confluences? ( $Y$ or if $N$ type ctrl-n $m c)$

Confluence 1: Distance Enters on $\underline{\mathbf{N O}}$ (LB or RB)

How many? -

Confluence 2: Distance NT

Enters on $\underline{\mathbf{B A}}$ (LB or RB)

Confluence comments (eg. confluence name):

\section{F. Geomorphic Channel Assessment}

107. Stage of reach evolution

1- Constructed

2- Stable

3- Aggraded

4- Degraded

5- Laterally unstable

6- Vertically and laterally unstable 
108. Evolution comments (Channel evolution not considering bridge effects; See HEC-20, Figure 1 for geomorphic descriptors): $\mathbf{N}$

$-$

$-$

$-$

$-$

$-$

$-$

NO CUT BANKS

$\mathbf{N}$ 


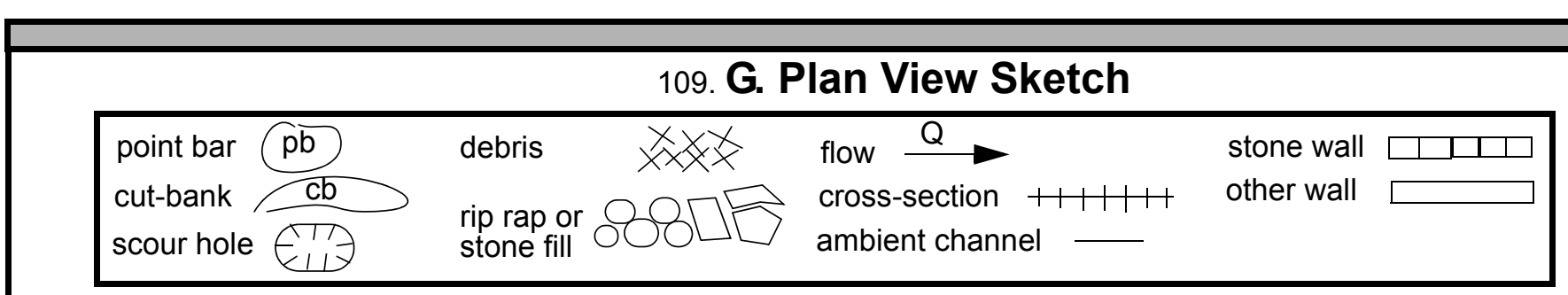


APPENDIX F:

SCOUR COMPUTATIONS 


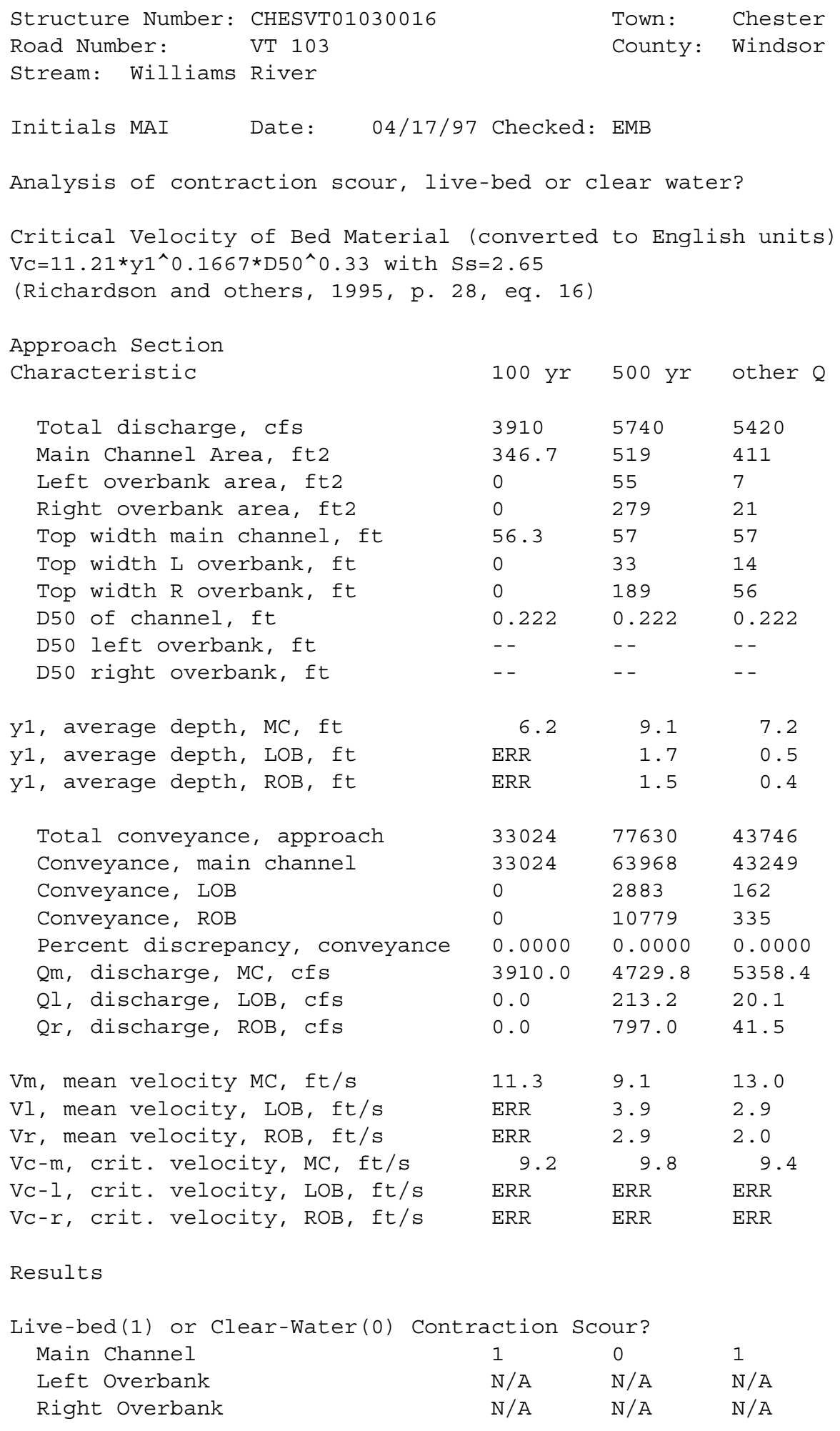




\begin{tabular}{|c|c|c|c|c|c|c|}
\hline \multicolumn{7}{|c|}{ 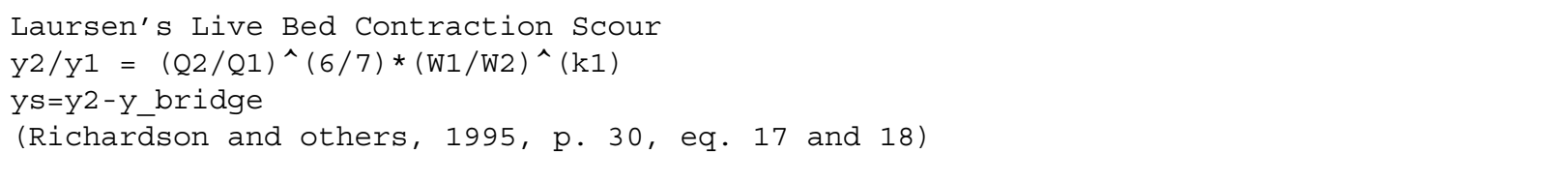 } \\
\hline & Approach & & & Bridge & & \\
\hline Characteristic & $100 \mathrm{yr}$ & $500 \mathrm{yr}$ & Other Q & $100 \mathrm{yr}$ & $500 \mathrm{yr}$ & Other $Q$ \\
\hline Q1, discharge, cfs & 3910 & 5740 & 5420 & 3910 & 4406 & 5420 \\
\hline Total conveyance & 33024 & 77630 & 43746 & 47608 & 52729 & 54509 \\
\hline Main channel conveyance & 33024 & 63968 & 43249 & 47608 & 52729 & 54509 \\
\hline Main channel discharge & 3910 & 4730 & 5358 & 3910 & 4406 & 5420 \\
\hline Area - main channel, ft2 & 346.7 & 519 & 411 & 401 & 522 & 448.4 \\
\hline (W1) channel width, ft & 56.3 & 57 & 57 & 58.3 & 72.3 & 72 \\
\hline (Wp) cumulative pier width, ft & 0 & 0 & 0 & 8 & 8 & 8 \\
\hline W1, adjusted bottom width(ft) & 56.3 & 57 & 57 & 50.3 & 64.3 & 64 \\
\hline D50, ft & 0.222 & 0.222 & 0.222 & & & \\
\hline w, fall velocity, ft/s (p. 32) & 3.85 & 3.85 & 3.85 & & & \\
\hline y, ave. depth flow, ft & 6.16 & 9.11 & 7.21 & 7.97 & 8.12 & 7.01 \\
\hline S1, slope EGL & 0.0133 & 0.0163 & 0.0164 & & & \\
\hline $\mathrm{P}$, wetted perimeter, $\mathrm{MC}$, ft & 61 & 62 & 62 & & & \\
\hline R, hydraulic Radius, ft & 5.592 & 8.371 & 6.629 & & & \\
\hline V*, shear velocity, ft/s & 1.548 & 2.096 & 1.871 & & & \\
\hline $\mathrm{V} * / \mathrm{w}$ & 0.402 & 0.544 & 0.486 & & & \\
\hline $\begin{array}{l}\text { Bed transport coeff., } \mathrm{kl},(0.59 \mathrm{if} \\
\mathrm{kl}\end{array}$ & $\begin{array}{l}\mathrm{V} * / \mathrm{w}<0.5 ; \\
0.59\end{array}$ & $\begin{array}{l}0.64 \text { if } \\
0.64\end{array}$ & $\begin{array}{l}.5<\mathrm{V} * / \mathrm{W}<2 ; \\
0.59\end{array}$ & ; 0.69 if & $\mathrm{V} * / \mathrm{w}>2.0$ & $0 \mathrm{p} .33)$ \\
\hline $\mathrm{y}^{2}$, depth in contraction, ft & 6.58 & 7.93 & 6.80 & & & \\
\hline ys, scour depth, ft (y2-y_bridge) & -1.39 & -0.19 & -0.21 & & & \\
\hline
\end{tabular}

Clear Water Contraction Scour in MAIN CHANNEL

$\mathrm{y}^{2}=\left(\mathrm{Q} 2^{\wedge} 2 /\left(131 * \mathrm{Dm}^{\wedge}(2 / 3) * \mathrm{~W} 2^{\wedge} 2\right)\right)^{\wedge}(3 / 7) \quad$ Converted to English Units

ys $=$ y2-y_bridge

(Richardson and others, 1995, p. 32, eq. 20, 20a)

$\begin{array}{llll}\text { Bridge section } & \text { Q100 } & \text { Q500 } & \text { Other Q } \\ \text { (Q) total discharge, cfs } & 3910 & 5740 & 5420 \\ \text { (Q) discharge thru bridge, cfs } & 0 & 4406 & 0 \\ \text { Main channel conveyance } & 0 & 52729 & 0 \\ \text { Total conveyance } & 0 & 52729 & 0 \\ \text { Q2, bridge MC discharge, cfs } & \text { ERR } & 4406 & \text { ERR } \\ \text { Main channel area, ft2 } & 0 & 522 & 0 \\ \text { Main channel width (normal), ft } & 0.0 & 72.3 & 0.0 \\ \text { Cum. width of piers in MC, ft } & 0.0 & 8.0 & 0.0\end{array}$




\begin{tabular}{|c|c|c|c|}
\hline W, adjusted width, ft & 0 & 64.3 & 0 \\
\hline Y_bridge (avg. depth at br.), ft & ERR & 8.12 & ERR \\
\hline Dm, median $(1.25 * D 50)$, ft & 0.2775 & 0.2775 & 0.2775 \\
\hline $\mathrm{y}^{2}$, depth in contraction, ft & ERR & 6.69 & ERR \\
\hline$p t h \quad$ (y2-ybri & $\mathrm{N} / \mathrm{A}$ & -1.43 & $\mathrm{~N} / \mathrm{A}$ \\
\hline
\end{tabular}

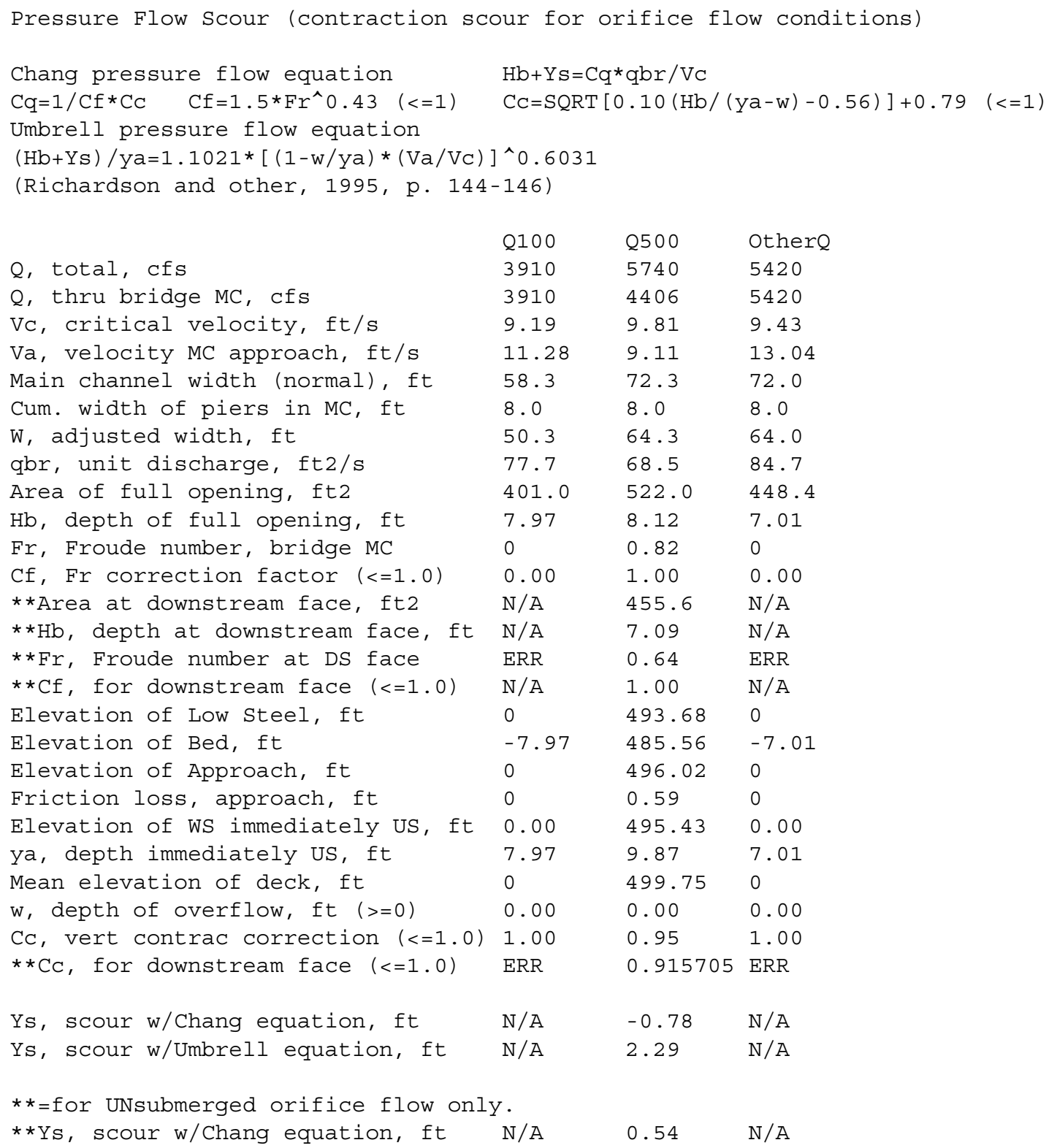




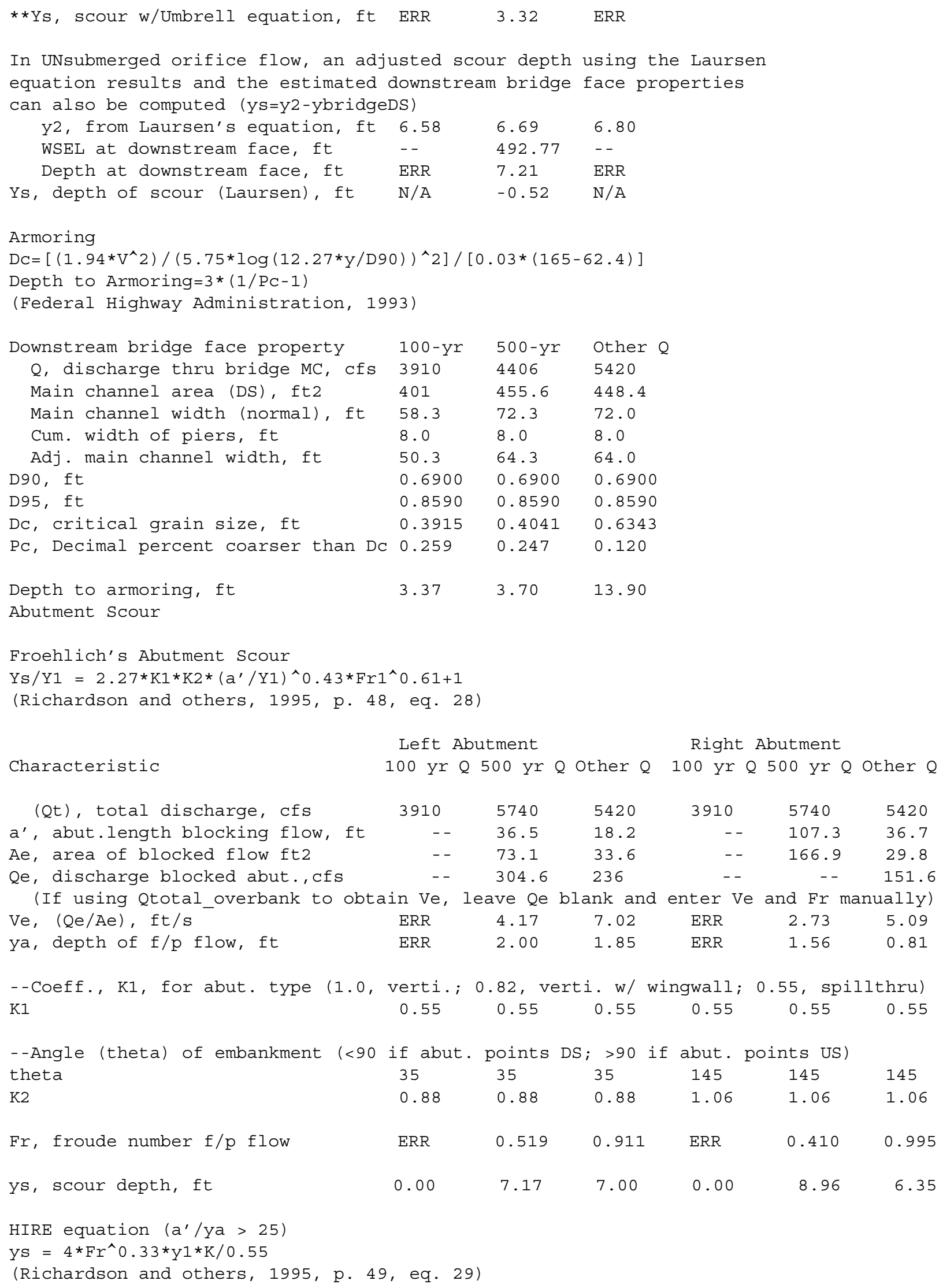






Pier Scour

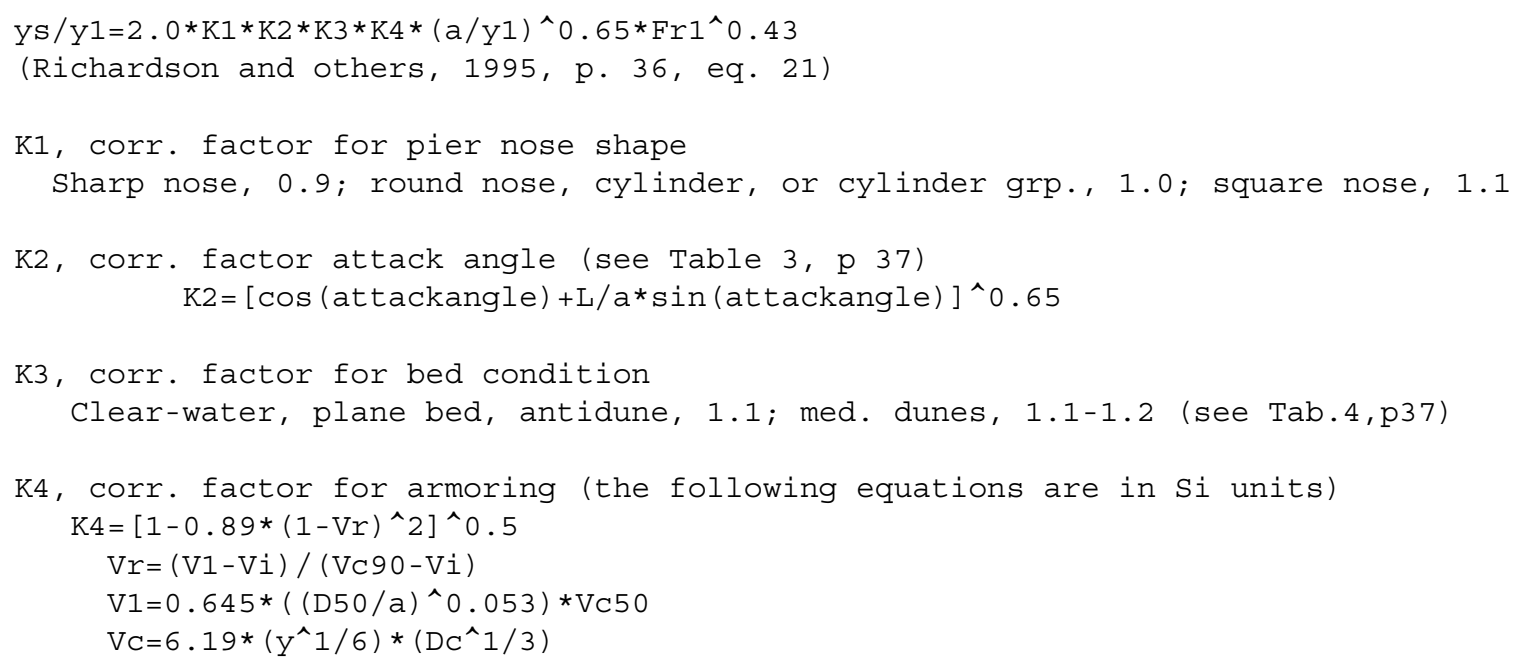


Note for round nose piers:

ys $<=2.4$ times the pier width (a) for Fr<=0.8

ys $<=3.0$ times the pier width (a) for Fr $>0.8$

$\begin{array}{llll}\text { Pier 1 } & \text { Q100 } & \text { Q500 } & \text { Qother } \\ \text { Pier stationing, ft } & 33.5 & 33.5 & 33.5 \\ \text { Area of WSPRo flow tube, ft2 } & 20.5 & 21.4 & 21.8 \\ \text { Skewed width of flow tube, ft } & 2.29 & 2.12 & 2.24 \\ \text { Y1, pier approach depth, ft } & 8.95 & 10.09 & 9.73 \\ \text { Y1 in meters } & 2.728 & 3.077 & 2.966 \\ \text { V1, pier approach velocity, ft/s } & 9.56 & 10.32 & 12.42 \\ \text { a, pier width, ft } & 4 & 4 & 4 \\ \text { L, pier length, ft } & 60 & 60 & 60 \\ \text { Fr1, Froude number at pier } & 0.563 & 0.572 & 0.702 \\ \text { Pier attack angle, degrees } & 0 & 0 & 0 \\ \text { K1, shape factor } & 1 & 1 & 1 \\ \text { K2, attack factor } & 1.00 & 1.00 & 1.00 \\ \text { K3, bed condition factor } & 1.1 & 1.1 & 1.1 \\ \text { D50, ft } & 0.222 & 0.222 & 0.222 \\ \text { D50, m } & 0.067662 & 0.067662 & 0.067662 \\ \text { D90, ft } & 0.69 & 0.69 & 0.69 \\ \text { D90, m } & 0.210302 & 0.210302 & 0.210302 \\ \text { Vc50,critical velocity(D50), m/s } & 2.982 & 3.042 & 3.023 \\ \text { Vc90, critical velocity(D90), m/s } & 4.351 & 4.439 & 4.412 \\ \text { Vi,incipient velocity,m/s } & 1.650 & 1.683 & 1.673 \\ \text { Vr, velocity ratio } & 0.468 & 0.531 & 0.771 \\ \text { K4, armor factor } & 0.86 & 0.90 & 0.98 \\ \text { Ys, scour depth (K4 applicable) ft } & 7.88 & 8.58 & 10.07\end{array}$

Pier 2

$\begin{array}{lll}\text { Q100 } & \text { Q500 } & \text { Qother } \\ 124.9 & 124.9 & 124.9 \\ 20.5 & 21.4 & 21.8 \\ 2.29 & 2.12 & 2.24 \\ 8.95 & 10.09 & 9.73 \\ 2.728 & 3.077 & 2.966 \\ 9.56 & 10.32 & 12.4 \\ 4 & 4 & 4 \\ 60 & 60 & 60 \\ 0.563 & 0.572 & 0.700 \\ 0 & 0 & 0 \\ 1 & 1 & 1 \\ 1.00 & 1.00 & 1.00 \\ 1.1 & 1.1 & 1.1\end{array}$




$\begin{array}{llll}\text { D50, ft } & 0.222 & 0.222 & 0.222 \\ \text { D50, m } & 0.067662 & 0.067662 & 0.067662 \\ \text { D90, ft } & 0.69 & 0.69 & 0.69 \\ \text { D90, m } & 0.210302 & 0.210302 & 0.210302 \\ \text { Vc50, critical velocity (D50), m/s } & 2.982 & 3.042 & 3.023 \\ \text { Vc90, critical velocity(D90), m/s } & 4.351 & 4.439 & 4.412 \\ \text { Vi, incipient velocity, m/s } & 1.650 & 1.683 & 1.673 \\ \text { Vr, velocity ratio } & 0.468 & 0.531 & 0.769 \\ \text { K4, armor factor } & 0.86 & 0.90 & 0.98 \\ \text { Ys, scour depth, (K4 applicable) ft } 7.88 & 8.58 & 10.06\end{array}$

Pier rip-rap sizing

$\mathrm{D} 50=0.692(\mathrm{~K} * \mathrm{~V})^{\wedge} 2 /(\mathrm{Ss}-1) * 2 * \mathrm{~g}$

(Richardson and others, 1995, p.115, eq. 83)

Pier-shape coefficient (K), round nose, 1.5 ; square nose, 1.7
Characteristic avg. channel velocity, $\mathrm{V},(\mathrm{Q} / \mathrm{A})$ :
(Mult. by 0.9 for bankward piers in a straight, uniform reach,
up to 1.7 for a pier in main current of flow around a bend)

Pier 1

Q100 Q500 Qother

$\mathrm{K}$, pier shape coeff.

$1.5 \quad 1.5 \quad 1.5$

$\mathrm{V}$, velocity on pier, ft/s

$\begin{array}{lll}9.75 & 9.67 & 12.09\end{array}$

D50, median stone diameter, ft

$\begin{array}{lll}1.39 & 1.37 & 2.14\end{array}$

Pier 2

$\mathrm{K}$, pier shape coeff.

$\begin{array}{lll}1.5 & 1.5 & 1.5\end{array}$

$\mathrm{V}$, velocity on pier, ft/s

9.75

9.67

12.09

D50, median stone diameter, ft

$\begin{array}{lll}1.39 & 1.37 & 2.14\end{array}$


